\title{
Spatio-temporal trends in diversity of demersal fish assemblages in the Mediterranean
}

\begin{abstract}
Summary: The high species richness, coupled with high proportion of endemism, makes the Mediterranean one of the world's 'biodiversity hotspots'. However, the continuous increase in fisheries in the last few decades has led to the overexploitation of their main commercial stocks. Using fishery-independent data collected under the framework of the MEDITS trawl surveys carried out over the last 20 years, we study the demersal fish diversity pattern in the Mediterranean at a large spatial and temporal scale to determine whether it is being affected by the general fishing overexploitation of the demersal resources. The detected diversity trends are compared with the spatio-temporal variation in bottom trawl fishing effort in the Mediterranean. Our results show a stability and even recovery of demersal fish diversity in the Mediterranean together with higher diversity values on the continental shelves of the Balearic Islands, Sardinia, Sicily and the Aegean Sea. At large temporal and spatial scales, the high diversity of demersal assemblages in the Mediterranean is associated with a reduction in bottom trawl fishing effort. The inclusion of species other than target ones through diversity indices is important in the implementation of an ecosystem-based fisheries management.
\end{abstract}

Keywords: biodiversity; fish assemblages; MEDITS; bottom trawling; fishing effort; Mediterranean Sea.

Tendencias espacio-temporales en la diversidad de peces demersales del Mediterráneo

Resumen: Debido a su alta riqueza específica y su gran proporción de organismos endémicos, el Mediterráneo es considerado un punto caliente de biodiversidad. No obstante el continuo crecimiento de las pesquerías en las últimas décadas ha 
desembocado en una sobrexplotación de sus principales stocks comerciales. A través de datos independientes de las pesquerías recogidos en el marco de las campañas MEDITS desarrolladas durante las dos últimas décadas se ha estudiado el patrón de diversidad de peces demersales en el Mediterráneo a través de largas escalas temporales y espaciales para evaluar si este patrón se ve afectado por el estado general de sobrexplotación de sus recursos demersales. A continuación las tendencias detectadas en la diversidad han sido comparadas a la variación espacio-temporal del esfuerzo de la pesca de arrastre a través del Mediterráneo. Nuestros resultados muestran una estabilidad e incluso recuperación de la diversidad de peces demersales en el Mediterráneo junto a valores altos de diversidad en las plataformas continentales de las Islas Baleares, Cerdeña, Sicília y el mar Egeo. La alta diversidad de las asociaciones de peces demersales a escala tanto espacial como temporal está asociada a una reducción del esfuerzo pesquero. La inclusión de especies distintas a las objetivo a través de índices de diversidad es relevante en la implementación de la aproximación ecosistémica a la gestión de las pesquerías.

Palabras clave: biodiversidad; asociaciones de peces; MEDITS; arrastre de fondo; esfuerzo pesquero; mar Mediterráneo.

Citation/Cómo citar este artículo: Farriols M.T., Ordines F., Carbonara P., Casciaro L., Di Lorenzo M., Esteban A., Follesa C., García-Ruiz C., Isajlovic I., Jadaud A., Ligas A., Manfredi C., Marceta B., Peristeraki P., Vrgoc N., Massutí E. 2019. Spatio-temporal trends in diversity of demersal fish assemblages in the Mediterranean. Sci. Mar. 83S1: 189-206. https://doi. org/10.3989/scimar.04977.13A

Editor: M.T. Spedicato.

Received: April 18, 2018. Accepted: July 11, 2019. Published: September 26, 2019.

Copyright: (C) 2019 CSIC. This is an open-access article distributed under the terms of the Creative Commons Attribution 4.0 International (CC BY 4.0) License.

\section{INTRODUCTION}

The Mediterranean is considered one of the Large Marine Ecosystems of the world, owing to its bathymetry, hydrography, productivity and trophic webs (Duda and Sherman 2002). It is a semi-enclosed sea connected to the Atlantic Ocean through the Gibraltar Strait, to the Black Sea through the Dardanelles Strait and to the Red Sea through the artificial Suez Channel (Fig. 1). It acts as a concentration basin, and evaporation is higher in its eastern basin, causing the water level to decrease and salinity to increase from west to east (Coll et al. 2010). While temperature also increases eastwards (Coll et al. 2010), surface productivity, organic matter availability at the seafloor and the biomass of megabenthic fauna of deep ecosystems decrease eastwards (Bosc et al. 2004, Danovaro et al. 1999, Tecchio et al. 2011). The Mediterranean has narrow continental shelves and a large area of open sea. In fact, the continental shelf covers about $20 \%$ of the Mediterranean bottoms, whereas the slope covers about $60 \%$ (Sardà et al. 2004). Therefore, a large part of this basin can be classified as deep sea (Coll et al. 2010).

The high species richness, coupled with a high proportion of endemism, makes the Mediterranean one of the world's 'biodiversity hotspots' (Moranta et al. 2008, Coll et al. 2010, Lejeusne et al. 2010). Environmental variables such as temperature, productivity and distance from the Strait of Gibraltar have been shown to be causes of fish species richness distribution (Ben Rais Lasram et al. 2009, Meléndez et al. 2017). However, this high biodiversity is presently threatened by the combined action of anthropogenic impacts, introduction of alien species and climate change (Bianchi et al. 2012). Among human activities, fisheries are one of the most important factors affecting marine resources and ecosystems.

It is well known that fisheries have profoundly modified the structure of marine ecosystems (Dayton et al. 1995, Hall 1999, Kaiser and de Groot 2000). Effects of fishing on marine ecosystems include shifts in the food-web structure due to changes in predator-prey relationships (Kaiser et al. 2002); changes in size structure due to vulnerability and selection of fishing for large individuals (Gislason 2002, Jennings and Dulvy 2005, Daan et al. 2005); genetic selection of species with particular life-history traits, such as a higher growth rate and earlier age-at-maturity (Fromentin and Fonteneau 2001, Jørgensen et al. 2007); changes in the spatial distribution of target species (e.g. Ciannelli et al. 2013); effects on the population of non-target species (Pranovi et al. 2001, Ordines et al. 2014); and decrease of habitat complexity and changes on the benthic community structure (e.g. Callaway et al. 2002).

The natural resources of the Mediterranean have been subject to human exploitation since ancient times, when coastal communities started to use different fishing gears, some of which are still in use (Farrugio et al. 1993). Dramatic long-term changes in marine communities took place before the industrialization of fisheries that occurred in the 1950s, and have already been documented in some areas, such as the Adriatic Sea (Fortibuoni et al. 2010). Until 1950, the exploitation of Mediterranean resources was limited to fishing areas shallower than $200 \mathrm{~m}$ depth. In the last few decades, with the decline of stocks on the continental shelf, increasing market demand and the introduction of new technologies, trawl fisheries have expanded offshore and towards the deeper waters of the continental slope (Roberts 2002, Morato et al. 2006) to target valuable resources such as red shrimps (e.g. Demestre and Martín 1993, Guijarro et al. 2008, Masnadi et al. 2018).

In this area, fisheries are assessed within the framework of the General Fisheries Commission for the Mediterranean (GFCM), the regional fisheries management organization of the Mediterranean. Of the 27 Mediterranean stocks of fishing target species assessed by the GFCM in its last report, about $80 \%$ were considered overexploited (GFCM 2016). The presence of a high diversity of species and the absence of large monospecific stocks comparable to those inhabiting some wide areas of the open oceans are characteristic 


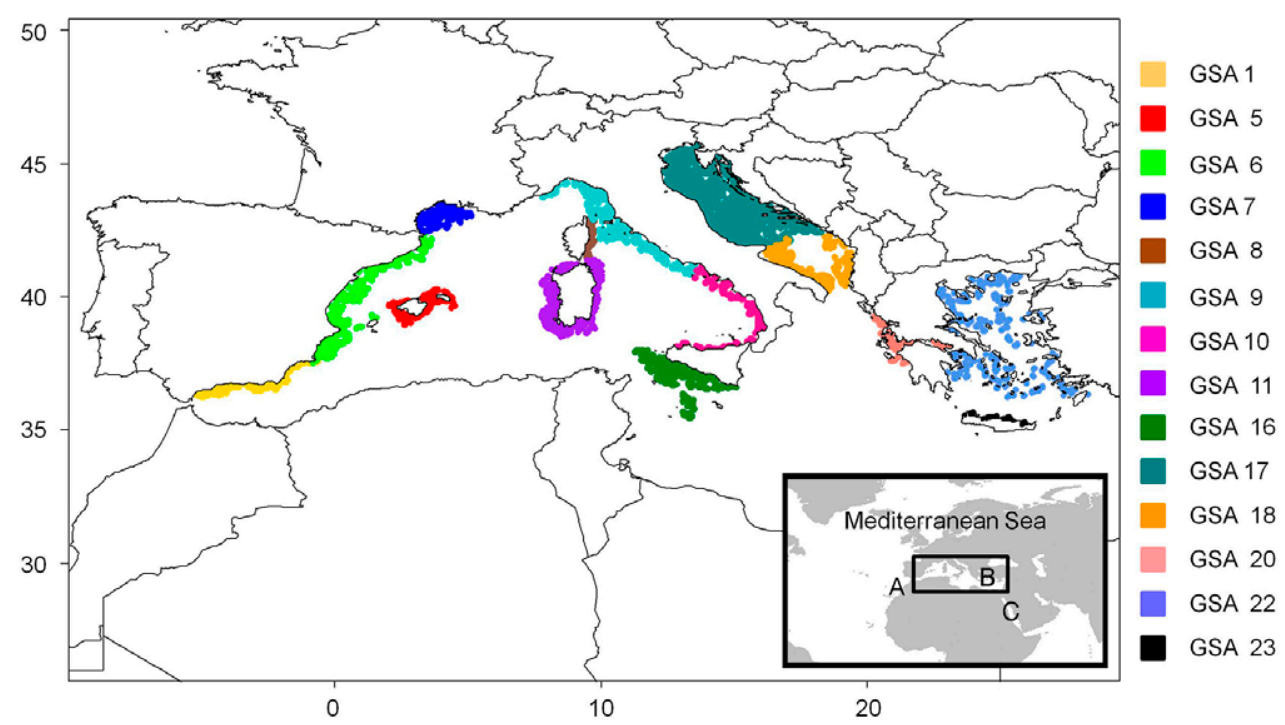

Fig. 1. - Map of the study area showing the 17540 hauls sampled between 1994 and 2015 in 15 geographical sub-areas (GSAs). Each colour corresponds to one of the GSAs defined by the GFCM (http://www.gfcm.org). The smaller map shows the location of the Mediterranean and its connections to the Atlantic Ocean through the Gibraltar Strait (A), the Black Sea through the Dardanelles Strait (B) and the Red Sea through the artificial Suez Channel (C).

of the Mediterranean demersal fisheries (Farrugio et al. 1993). Assessment at a community level is therefore crucial, particularly due to the multispecies nature of the bottom trawl fishery and also because a decline in the diversity of demersal assemblages has been reported due to fishing exploitation (e.g. Ungaro et al. 1998, Sabatini et al. 2013, Farriols et al. 2017). Assessment at a community level is also a requirement for the implementation of an ecosystem-based management of fisheries (Browman and Stergiou 2004).

The aim of this work is to study the demersal fish diversity pattern in the Mediterranean at a large spatial and temporal scale and to assess whether this pattern is being affected by the general fishing overexploitation of demersal resources in the area. To do so, we used fishery-independent data collected under the framework of the MEDITS trawl surveys carried out during the last 20 years. The detected trends were compared with the spatio-temporal variation in bottom trawl fishing effort in the Mediterranean Sea.

\section{MATERIALS AND METHODS}

\section{Data}

Demersal fish were collected during MEDITS bottom trawl surveys conducted from 1994 to 2015 in 14 geographical sub-areas (GSAs) along the European coasts of the Mediterranean Sea. Some GSAs have gaps in their sampling years: i) GSA 5 started sampling in 2001; ii) there are no data in 2002 for GSA 8 (technical problem of the boat); and iii) there are no data for 2002 , 2007, 2009-2013 and 2015 for GSAs 20, 22 and 23. Sampling was performed during spring-summer in daylight hours using the GOC73 experimental gear, whose efficiency for catching demersal species has been tested by Fiorentini et al. (1999) and Dremière et al. (1999). For more details about the sampling strategy and protocol see Bertrand et al. (2002) and the MEDITS hand-
Table 1. - Name of the areas and number of samples analysed for each GSA.

\begin{tabular}{llr}
\hline GSA & Area & Samples \\
\hline GSA 1 & Northern Alboran Sea & 743 \\
GSA 5 & Balearic Islands & 650 \\
GSA 6 & Northern Spain & 1459 \\
GSA 7 & Gulf of Lions & 1143 \\
GSA 8 & Corsica & 451 \\
GSA 9 & Ligurian, northern and central Tyrrhenian Sea & 2468 \\
GSA 10 & Central and southern Tyrrhenian Sea & 1333 \\
GSA 11 & Sardinia & 1811 \\
GSA 16 & Strait of Sicily & 1492 \\
GSA 17 & Northern Adriatic Sea & 2296 \\
GSA 18 & Southern Adriatic Sea & 1684 \\
GSA 20 & Eastern Ionian Sea & 308 \\
GSA 22 & Aegean Sea & 1427 \\
GSA 23 & Crete & 175 \\
\hline
\end{tabular}

book, instruction manual version 9 (MEDITS Working Group 2017).

A total of 17540 hauls performed between 46 and 866 m depth were analysed (Table 1, Fig. 1). Hauls shallower than $46 \mathrm{~m}$ depth were excluded from the analysis because they could not be found for all GSAs. The catch of each sample was sorted, identified to species level, counted, weighed and standardized to square $\mathrm{km}$ by using the horizontal opening of the net and the distance covered in each haul. Species with a pelagic or mesopelagic behaviour, like most species of the families Myctophydae (e.g. Ceratoscopelus maderensis) and Cupleidae (e.g. Engraulis encrasicolus), were excluded from the analysis. A species accumulation curve for each GSA was performed and we confirmed that differences in number of species were not due to differences in the number of hauls considered for each GSA (Table 1, Fig. S1).

\section{Fish assemblages and diversity}

Cluster analysis was used to analyse the structure of demersal fish assemblages and to identify different assemblages according to depth strata in each GSA. Rela- 
tionships among samples were detected by hierarchical agglomerative clustering with group-average linkage after a forth root transformation of the data. The distance used to make groups was the Bray-Curtis similarity. These analyses were performed using PRIMER 7 (Clarke et al. 2014). The calculus of diversity indices explained below was made taking into account the groups of samples obtained from the cluster analysis.

The $N_{90}$ diversity index was calculated following the procedure described by Farriols et al. (2015). It is the mean number of species contributing up to $90 \%$ of within-group similarity calculated from abundance data expressed as $\mathrm{N} \mathrm{km}^{-2}$ and assigned a priori to groups. The calculation of $N_{90}$ starts with the calculation of the contribution of each species to the withingroup similarity using the Bray-Curtis similarity index (Bray and Curtis 1957), as proposed by Clarke (1993):

$$
S_{j k}(i)=100 \times \frac{2 \times \min \left(y_{i j}, y_{i k}\right)}{\sum_{i=1}^{p}\left(y_{i j}+y_{i k}\right)} ;
$$

where $y_{\mathrm{ij}}$ is the abundance of the species $i$ at the sampling site $j, y_{\mathrm{ik}}$ is the abundance of the species $i$ at the sampling site $k, p$ is the total number of species in $j$ and $k$, and $\min \left(y_{\mathrm{ij}}, y_{\mathrm{ik}}\right)$ is the minimum value of the abundance of species $i$ between the sampling sites $j$ and $k$, also considering zeros.

The contribution of each species $i$ to the total similarity of the group $S_{\mathrm{i}}$ is the mean value of $S_{\mathrm{jk}}(i)$ for the assigned group, and the total similarity in a group ( $\mathrm{Sim}$ ) is the addition of $S_{\mathrm{i}}$ for all the species in the group:

$$
\operatorname{Sim}=\sum_{i=1}^{p} S_{i} .
$$

Then, the contribution of $S_{\mathrm{i}}$ is calculated as a percentage of Sim. Species contributions are calculated for each re-sampling in a jack-knife routine, which removes a number of samples each time, producing lists of contribution to similarity by species in each re-sampling. Because the groups of samples for each GSA, strata and year were large, we removed $10 \%$ of the samples in each re-sampling with a $50 \%$ replacement. That is, $50 \%$ of samples removed in a re-sampling must be different from previous ones. In this way, we obtain values of deviation for $N_{90}$ other than 0 for groups with a large number of observations. The $N_{90}$ diversity index is the mean number of species which accumulate up to $90 \%$ of within-group similarity in all the re-samplings. $N_{90}$ was calculated using R scripts, version 3.1.1 (R Core Team 2014). Similarity percentage analysis (SIMPER) for each group of samples was also undertaken to see their species composition.

Diversity indices, such as species richness $(S)$ and Pielou evenness $\left(J^{\prime}\right)$, which have shown some kind of response to fishing impact for demersal fish assemblages in the Mediterranean (Farriols et al. 2017), were also included in this work. These traditional indices are also helpful for comparison with previous works. $S$ is the raw number of species in each haul and $J$ ' was calculated as follows:

$$
J^{\prime}=\frac{\sum_{i=1}^{S} p_{i} \ln p_{i}}{\ln S} ;
$$

where $p_{i}$ is the proportion of all individuals belonging to species $i$ and $S$ is the total number of species in the sample.

\section{Fishing effort}

Information on annual fishing effort was collected from the working group reports of the GFCM (http:// www.fao.org/gfcm/data/safs/en/) and the Scientific, Technical and Economic Committee for Fisheries (STECF, https://stecf.jrc.ec.europa.eu/reports/medbs). Fishing effort data were compiled by trawl fleet targeting different species. The units vary between the different reports, being mainly provided in terms of number of vessels, kilowatts per days at sea and gross tonnage per days at sea (see Table S1).

To estimate fishing effort in each depth stratum obtained from cluster analysis, the strata were associated with the main target species of the fleets. Because target species varied between GSAs, we considered i) Mullus barbatus or Mullus surmuletus for the continental shelf; ii) Nephrops norvegicus or Parapenaeus longirostris for the shelf break/upper slope; and iii) Aristeus antennatus or Aristaeomorpha foliacea for the lower slope.

To compare temporal trends in fishing effort and demersal fish diversity, the longest series of fishing effort available for each GSA and depth stratum regardless of the kind of units were selected. When we found no values of fishing effort for a certain GSA, experts were contacted to obtain a trend in number of vessels in that area.

\section{Temporal and spatial analysis}

In order to analyse temporal trends in diversity, linear regressions were fitted to the mean values of $S, J$ ' and $N_{90}$ for each year, GSA and depth stratum. Linear regression analyses with the annual values of fishing effort in each GSA (see Fishing effort section in Materials and Methods) and depth stratum were also performed. The exploration of the scatter plots of the time series together with the comparison of Pearson (assuming linear pattern) and Spearman (suitable also for other monotonic patterns than the linear) correlation coefficients were done. The values of both correlation coefficients were similar, indicating that the detected trends could be fitted using a simple linear model. Thus, the linear regression and the Pearson coefficient of correlation were presented along with the coefficient of determination (i.e. variance explained). These analyses were carried out with $\mathrm{R}$, version 3.1.1 (R Core Team 2014).

In order to observe spatial differences in diversity by GSA, time series of mean values and standard deviation of each diversity index (see Data section for years included in each GSA) were plotted. For those series with a significant temporal trend, the diversity values at the beginning and the end of the time series were plotted instead of mean values and standard deviation.

SIMPER analysis for each group of samples from $N_{90}$ was also performed to see differences in species 

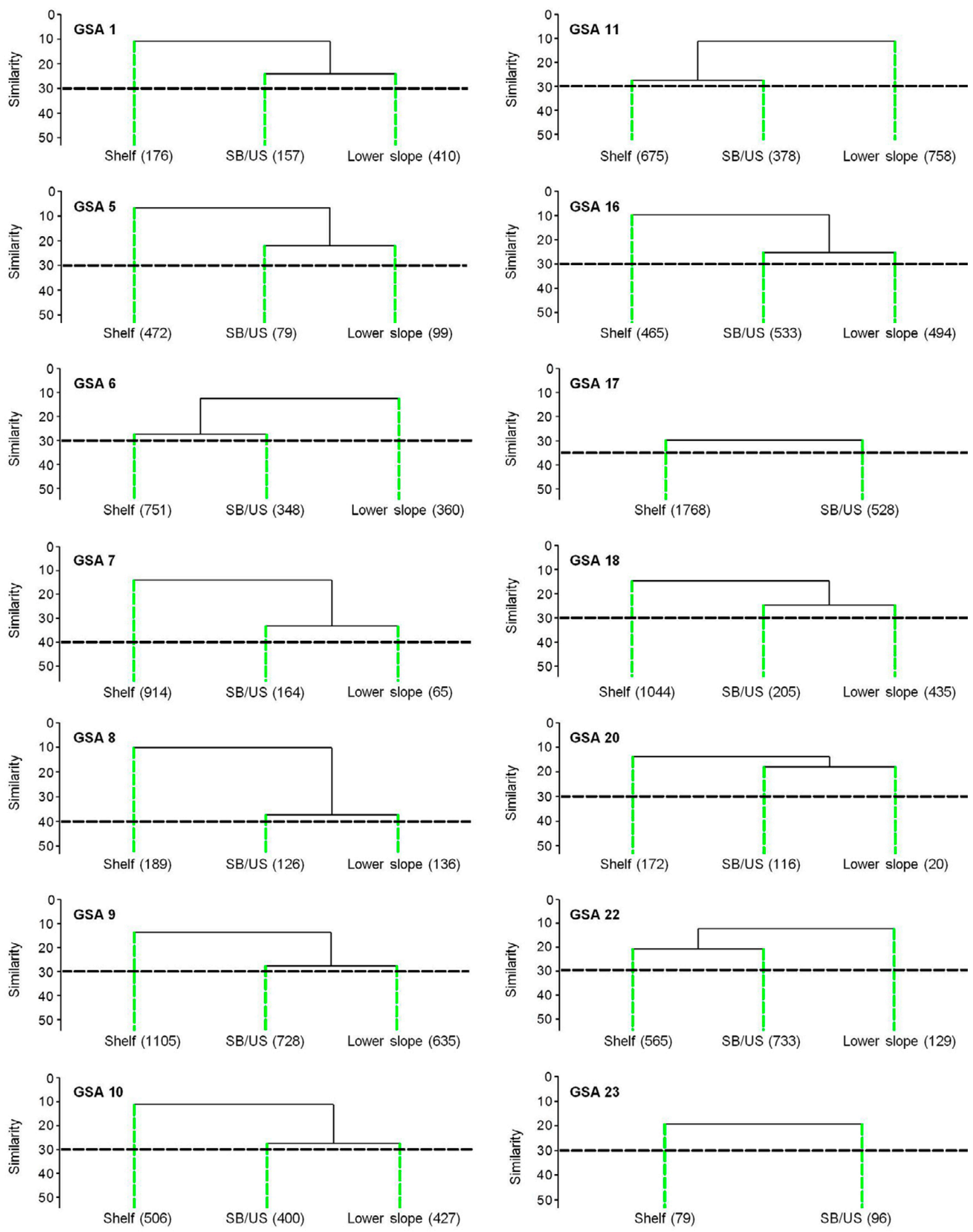

Fig. 2. - Cluster of samples obtained from MEDITS surveys. The data used for the cluster analysis were the double root transformation of abundances of demersal fish species for each sample during the sampling period of each GSA. The dashed line shows the similarity level used to classify the depth strata: shelf, shelf break/upper slope (SB/US) and lower slope. The number in brackets represents the number of samples in each depth stratum. 
composition in each GSA. The percentage of contribution of each species to within-group similarity was calculated as the mean value of species contributions to similarity, taking all groups of observations by year and stratum for each GSA into account.

\section{RESULTS}

\section{Community structure}

Results from cluster analysis detecting main fish assemblages for each GSA are shown in Figure 2. Three groups of samples were selected from most GSAs, corresponding to a level of similarity of between $30 \%$ and $40 \%$. Maximum, minimum and mean depths of each cluster group per GSA were obtained. According to these depth values, samples were grouped in three different depth strata: shelf, shelf break/upper slope and lower slope (Table 2, Fig. 2). For GSAs 17 and 23 only two groups were selected. GSA 17 has no samples below $350 \mathrm{~m}$, and GSA 23 has a negligible sample number over $496 \mathrm{~m}$ (Table 2). For GSAs 7 and 20 samples in the lower slope group were not enough to calculate the $N_{90}$ throughout the time series, so both lower slope groups were omitted from the temporal and spatial analysis.

In 9 out of the 12 GSAs showing lower slope samples, samples from the shelf break/upper slope clustered with samples from the lower slope. The exceptions were GSAs 6, 11 and 22, where samples from the shelf break/ upper slope clustered with those from the continental shelf. Minimum, maximum and mean depths for each group of samples from cluster analysis are shown in Table 2. Mean depth of continental shelf samples ranged from $76 \mathrm{~m}$ in GSA 1 to $125 \mathrm{~m}$ in GSA 10, while for the shelf break/upper slope they ranged from $180 \mathrm{~m}$ in GSA 17 to $421 \mathrm{~m}$ in GSA 7, and for the lower slope between $496 \mathrm{~m}$ in GSA 11 and $699 \mathrm{~m}$ in GSA 7.

\section{Temporal trends}

Although the analysis of temporal evolution for $N_{90}, S$ and $J$ ' showed no significance in most GSAs and depth strata (Table 3, Fig. 3 and Figs S2-S4), some trends were detected. $N_{90}$ increased on the continental shelf of GSAs 1, 8 and 20, the shelf break/upper slope of GSAs 7, 11 and 18 and the lower slope of GSA 11 and only decreased on the shelf break/upper slope of GSA 5 (Table 3, Fig. 3 and Fig. S2). $S$ increased on the continental shelf of GSAs 8 and 10, the shelf break/upper slope of GSAs 7, 8, 10 and 22 and the lower slope of GSAs 8,10,11, 16 and 18 and decreased on the shelf break/upper slope of GSA 17 and the lower slope of GSA 9 (Table 3, Fig. 3 and Fig. S3). $J$ ' increased on the continental shelf of GSA 7, the shelf break/upper slope of GSAs 7 and 8 and the lower slope of GSA 11 and decreased on the continental shelf of GSAs 10 and 16 , the shelf break/upper slope of GSAs 5 and 22 and the lower slope of GSAs 1 and 8 (Table 3, Fig. 3 and Fig. S4). These trends were confirmed when the last year of the time series (2014) for GSAs 20, 22 and 23 was excluded (Table 3 ).
Table 2.-Minimum, maximum and mean depth of samples grouped in each depth stratum (shelf, shelf break/upper slope and lower slope) from cluster analysis for each GSA.

\begin{tabular}{|c|c|c|c|c|}
\hline GSA & Strata & $\begin{array}{l}\text { Minimum } \\
\text { depth }\end{array}$ & $\begin{array}{l}\text { Maximum } \\
\text { depth }\end{array}$ & $\begin{array}{l}\text { Mean } \\
\text { depth }\end{array}$ \\
\hline \multirow[t]{3}{*}{ GSA 1} & Shelf & 50 & 168 & 76 \\
\hline & Shelf break/upper slope & 118 & 373 & 203 \\
\hline & Lower slope & 219 & 807 & 519 \\
\hline \multirow{3}{*}{ GSA 5} & Shelf & 46 & 258 & 108 \\
\hline & Shelf break/upper slope & 316 & 698 & 402 \\
\hline & Lower slope & 581 & 756 & 678 \\
\hline \multirow[t]{3}{*}{ GSA 6} & Shelf & 50 & 147 & 84 \\
\hline & Shelf break/upper slope & 82 & 392 & 183 \\
\hline & Lower slope & 257 & 798 & 505 \\
\hline \multirow[t]{3}{*}{ GSA 7} & Shelf & 55 & 155 & 93 \\
\hline & Shelf break/upper slope & 214 & 705 & 421 \\
\hline & Lower slope & 414 & 866 & 699 \\
\hline \multirow{3}{*}{ GSA 8} & Shelf & 56 & 158 & 94 \\
\hline & Shelf break/upper slope & 261 & 510 & 350 \\
\hline & Lower slope & 405 & 583 & 510 \\
\hline \multirow[t]{3}{*}{ GSA 9} & Shelf & 50 & 399 & 118 \\
\hline & Shelf break/upper slope & 141 & 640 & 340 \\
\hline & Lower slope & 364 & 757 & 559 \\
\hline \multirow[t]{3}{*}{ GSA 10} & Shelf & 50 & 350 & 125 \\
\hline & Shelf break/upper slope & 170 & 616 & 365 \\
\hline & Lower slope & 339 & 693 & 594 \\
\hline \multirow[t]{3}{*}{ GSA 11} & Shelf & 50 & 292 & 97 \\
\hline & Shelf break/upper slope & 109 & 357 & 198 \\
\hline & Lower slope & 219 & 725 & 496 \\
\hline \multirow[t]{3}{*}{ GSA 16} & Shelf & 51 & 220 & 94 \\
\hline & Shelf break/upper slope & 108 & 654 & 333 \\
\hline & Lower slope & 436 & 794 & 630 \\
\hline \multirow[t]{2}{*}{ GSA 17} & Shelf & 50 & 235 & 91 \\
\hline & Shelf break/upper slope & 62 & 332 & 180 \\
\hline \multirow[t]{3}{*}{ GSA 18} & Shelf & 50 & 349 & 104 \\
\hline & Shelf break/upper slope & 111 & 397 & 270 \\
\hline & Lower slope & 247 & 732 & 501 \\
\hline \multirow[t]{3}{*}{ GSA 20} & Shelf & 55 & 189 & 94 \\
\hline & Shelf break/upper slope & 149 & 664 & 379 \\
\hline & Lower slope & 483 & 800 & 654 \\
\hline \multirow[t]{3}{*}{ GSA 22} & Shelf & 50 & 340 & 109 \\
\hline & Shelf break/upper slope & 107 & 708 & 336 \\
\hline & Lower slope & 337 & 791 & 579 \\
\hline \multirow[t]{2}{*}{ GSA 23} & Shelf & 57 & 155 & 91 \\
\hline & Shelf break/upper slope & 115 & 496 & 245 \\
\hline
\end{tabular}

When quantitative analysis in temporal evolution of fishing effort could be made, the detected significance mainly showed a decreasing trend (Table 4, Fig. 3). This is the case of the continental shelf in GSAs 1, 5, 6 and 7, the shelf break/upper slope in GSAs 1, 11, 17 and 18 and the lower slope in GSAs 5 and 11. It increased only on the continental shelf and the lower slope of GSA 18. Expert knowledge suggested increasing trends in fishing effort for the lower slope in GSAs 20,22 and 23 and decreasing trends on the continental shelf of GSAs 8, 9, 16, 20, 22 and 23 and on the lower slope of GSAs 1, 7 and 8 (Table 4, Fig. 3).

In 6 of the 7 cases in which an increment of $N_{90}$ was detected, it coincided with a decrease in fishing effort (Tables 3-4, Fig. 3). Of the 11 cases showing increases in species richness, $S$, only in 3 cases was the increase in $S$ coupled with a decrease in fishing effort. In 5 cases there was no trend in fishing effort, while in only one case the increase in $S$ was coupled with an increase in fishing effort. In 2 cases, no information on the temporal evolution of fishing effort was available (Tables 3-4, Fig. 3). 10 GSAs showed significant trends in Pielou eveness, $J$ '; in 2 of them $J^{\prime}$ increased and fishing effort decreased, while 3 GSAs showed a decrease in both $J$ ' and fishing 
Table 3. - Results of linear regression analysis of the time series for $N_{90}$, species richness $(S)$ and Pielou evenness ( $J$ ') for each GSA and depth stratum (shelf, shelf break/upper slope and lower slope). Slope values of the adjusted linear regressions (b), adjusted R-squared values and p-values (p) are presented. *, p <0.05; **, p <0.01; ***, p <0.001. For GSAs 20, 22 and 23: a results for time series 1994-2006; and b results

\begin{tabular}{|c|c|c|c|c|c|c|c|c|c|c|}
\hline \multirow[b]{2}{*}{ Index } & \multirow[b]{2}{*}{ GSA } & \multicolumn{3}{|c|}{ Shelf } & \multicolumn{3}{|c|}{ Shelf break/upper slope } & \multicolumn{3}{|c|}{ Lower slope } \\
\hline & & $\mathrm{b}$ & Adjusted $\mathrm{R}^{2}$ & $\mathrm{p}$ & $\mathrm{b}$ & Adjusted $\mathrm{R}^{2}$ & $p$ & $\mathrm{~b}$ & Adjusted $\mathrm{R}^{2}$ & $\mathrm{p}$ \\
\hline \multirow[t]{17}{*}{$N_{90}$} & GSA 1 & 0.209 & 0.051 & $*$ & 0.047 & -0.050 & 0.383 & 0.001 & 0.430 & 0.955 \\
\hline & GSA 5 & -0.090 & -0.010 & 0.287 & -0.286 & 0.473 & $* *$ & 0.037 & -0.052 & 0.565 \\
\hline & GSA 6 & -0.027 & -0.029 & 0.683 & 0.063 & -0.034 & 0.321 & -0.112 & 0.031 & 0.059 \\
\hline & GSA 7 & 0.041 & 0.200 & 0.462 & 0.079 & 0.391 & * & & & \\
\hline & GSA 8 & 0.195 & -0.052 & $* *$ & 0.089 & 0.294 & 0.070 & 0.041 & 0.376 & 0.175 \\
\hline & GSA 9 & -0.005 & -0.044 & 0.923 & -0.027 & 0.105 & 0.483 & -0.013 & -0.049 & 0.493 \\
\hline & GSA 10 & -0.101 & 0.463 & 0.128 & 0.068 & 0.005 & 0.121 & -0.014 & 0.025 & 0.523 \\
\hline & GSA 11 & 0.084 & -0.031 & 0.136 & 0.090 & 0.119 & * & 0.083 & 0.338 & $*$ \\
\hline & GSA 16 & -0.066 & 0.455 & 0.398 & 0.019 & 0.025 & 0.593 & 0.012 & -0.044 & 0.540 \\
\hline & GSA 17 & 0.012 & 0.088 & 0.540 & 0.013 & 0.083 & 0.798 & & & \\
\hline & GSA 18 & -0.036 & 0.004 & 0.647 & 0.141 & -0.046 & $*$ & -0.036 & 0.031 & 0.111 \\
\hline & GSA $20^{\mathrm{a}}$ & 0.487 & 0.503 & $* *$ & 0.115 & -0.066 & 0.553 & & & \\
\hline & GSA $20^{\mathrm{b}}$ & 0.315 & -0.066 & $* *$ & 0.225 & 0.007 & 0.069 & & & \\
\hline & GSA $22^{\mathrm{a}}$ & 0.054 & -0.065 & 0.577 & -0.110 & 0.023 & 0.289 & -0.053 & -0.003 & 0.351 \\
\hline & GSA $22^{b}$ & 0.064 & -0.070 & 0.279 & 0.044 & 0.344 & 0.579 & 0.015 & 0.045 & 0.706 \\
\hline & GSA $23^{a}$ & 0.075 & 0.061 & 0.231 & -0.156 & -0.007 & 0.360 & & & \\
\hline & GSA $23^{b}$ & 0.099 & -0.090 & 0.098 & 0.038 & 0.152 & 0.740 & & & \\
\hline \multirow[t]{17}{*}{$S$} & GSA 1 & -0.044 & -0.040 & 0.658 & 0.010 & -0.049 & 0.898 & 0.036 & 0.005 & 0.305 \\
\hline & GSA 5 & 0.013 & -0.082 & 0.914 & -0.136 & 0.092 & 0.154 & -0.089 & -0.005 & 0.351 \\
\hline & GSA 6 & -0.030 & -0.044 & 0.728 & 0.090 & 0.018 & 0.254 & -0.017 & -0.041 & 0.674 \\
\hline & GSA 7 & -0.055 & -0.017 & 0.427 & 0.142 & 0.331 & $* *$ & & & \\
\hline & GSA 8 & 0.161 & 0.169 & * & 0.149 & 0.180 & * & 0.134 & 0.203 & $*$ \\
\hline & GSA 9 & -0.027 & -0.026 & 0.504 & -0.023 & -0.026 & 0.505 & -0.061 & 0.151 & $*$ \\
\hline & GSA 10 & 0.122 & 0.138 & $*$ & 0.197 & 0.411 & $* * *$ & 0.165 & 0.336 & $* *$ \\
\hline & GSA 11 & 0.064 & 0.026 & 0.226 & 0.041 & -0.017 & 0.433 & 0.080 & 0.227 & $*$ \\
\hline & GSA 16 & 0.026 & -0.035 & 0.600 & 0.112 & 0.101 & 0.082 & 0.105 & 0.145 & $*$ \\
\hline & GSA 17 & 0.010 & -0.048 & 0.861 & -0.130 & 0.196 & $*$ & & & \\
\hline & GSA 18 & 0.041 & -0.031 & 0.550 & 0.109 & 0.055 & 0.152 & 0.142 & 0.278 & $* *$ \\
\hline & GSA $20^{\mathrm{a}}$ & 0.297 & 0.149 & 0.118 & 0.582 & 0.492 & $* *$ & & & \\
\hline & GSA $20^{\mathrm{b}}$ & 0.166 & 0.072 & 0.182 & 0.230 & 0.117 & 0.136 & & & \\
\hline & GSA $22^{\mathrm{a}}$ & 0.099 & -0.042 & 0.471 & 0.359 & 0.410 & $*$ & -0.251 & 0.465 & $*$ \\
\hline & GSA $22^{b}$ & 0.089 & 0.019 & 0.286 & 0.304 & 0.546 & $* *$ & -0.031 & -0.077 & 0.712 \\
\hline & GSA $23^{\mathrm{a}}$ & -0.021 & -0.111 & 0.957 & -0.095 & -0.088 & 0.742 & & & \\
\hline & GSA $23^{\mathrm{b}}$ & 0.274 & 0.035 & 0.257 & 0.134 & -0.034 & 0.466 & & & \\
\hline \multirow[t]{17}{*}{$J^{\prime}$} & GSA 1 & 0.003 & 0.051 & 0.160 & 0.000 & -0.050 & 0.988 & -0.004 & 0.430 & $* * *$ \\
\hline & GSA 5 & -0.003 & -0.010 & 0.370 & -0.020 & 0.473 & $* *$ & 0.002 & -0.052 & 0.562 \\
\hline & GSA 6 & 0.001 & -0.029 & 0.533 & 0.001 & -0.034 & 0.589 & -0.002 & 0.031 & 0.210 \\
\hline & GSA 7 & 0.004 & 0.200 & $*$ & 0.007 & 0.391 & $* *$ & & & \\
\hline & GSA 8 & 0.000 & -0.052 & 0.937 & 0.004 & 0.294 & $* *$ & -0.004 & 0.376 & $* *$ \\
\hline & GSA 9 & 0.001 & -0.044 & 0.745 & 0.002 & 0.105 & 0.077 & 0.000 & -0.049 & 0.874 \\
\hline & GSA 10 & -0.008 & 0.463 & $* * *$ & 0.002 & 0.005 & 0.304 & -0.002 & 0.025 & 0.229 \\
\hline & GSA 11 & -0.001 & -0.031 & 0.554 & 0.004 & 0.119 & 0.064 & 0.004 & 0.338 & $* *$ \\
\hline & GSA 16 & -0.005 & 0.455 & $* * *$ & 0.002 & 0.025 & 0.230 & 0.000 & -0.044 & 0.729 \\
\hline & GSA 17 & -0.002 & 0.088 & 0.098 & -0.004 & 0.083 & 0.104 & & & \\
\hline & GSA 18 & 0.002 & 0.004 & 0.312 & -0.001 & -0.046 & 0.790 & -0.001 & 0.031 & 0.211 \\
\hline & GSA $20^{\mathrm{a}}$ & -0.003 & -0.023 & 0.406 & -0.003 & -0.090 & 0.688 & & & \\
\hline & GSA $20^{\mathrm{b}}$ & -0.001 & -0.066 & 0.663 & 0.004 & 0.007 & 0.320 & & & \\
\hline & GSA $22^{a}$ & -0.002 & -0.059 & 0.549 & -0.013 & 0.673 & $* * *$ & -0.003 & -0.042 & 0.461 \\
\hline & GSA $22^{b}$ & 0.001 & -0.070 & 0.710 & -0.007 & 0.344 & $*$ & -0.004 & 0.045 & 0.237 \\
\hline & GSA $23^{\mathrm{a}}$ & -0.004 & -0.065 & 0.548 & -0.018 & 0.329 & $*$ & & & \\
\hline & GSA $23^{\mathrm{b}}$ & 0.000 & -0.090 & 0.937 & -0.009 & 0.152 & 0.093 & & & \\
\hline
\end{tabular}

Table 4. - Results of linear regression analysis of the time series of fishing effort of the longest series available for each GSA and depth stratum (shelf, shelf break/upper slope and lower slope). Slope values of the adjusted linear regressions (b), adjusted R-squared values and p-values (p) are presented. Qualitative values of slopes are obtained from expert knowledge. *, p <0.05; **, p <0.01; ***, p <0.001; ns, non-significant.

\begin{tabular}{|c|c|c|c|c|c|c|c|c|c|}
\hline \multirow[b]{2}{*}{ GSA } & \multicolumn{3}{|c|}{ Shelf } & \multicolumn{3}{|c|}{ Shelf break/upper slope } & \multicolumn{3}{|c|}{ Lower slope } \\
\hline & $\mathrm{b}$ & Adjusted $\mathrm{R}^{2}$ & $\mathrm{p}$ & $\mathrm{b}$ & Adjusted $\mathrm{R}^{2}$ & $\mathrm{p}$ & $\mathrm{b}$ & Adjusted $\mathrm{R}^{2}$ & $\mathrm{p}$ \\
\hline GSA 1 & -8.800 & 0.717 & $*$ & -10.890 & 0.865 & $* * *$ & Decreasing & & \\
\hline GSA 5 & -5.118 & 0.898 & $* * *$ & 7.500 & 0.163 & 0.175 & -7.530 & 0.526 & $* *$ \\
\hline GSA 6 & -11.659 & 0.808 & $* * *$ & 3.248 & 0.071 & 0.204 & 0.000 & 0.510 & 0.117 \\
\hline GSA 7 & -13.821 & 0.765 & $* *$ & & & & Decreasing & & \\
\hline GSA 8 & Decreasing & & & & & & Decreasing & & \\
\hline GSA 9 & Decreasing & & & 1.820 & -0.081 & 0.874 & 8.109 & -0.088 & 0.669 \\
\hline GSA 10 & Increasing & & ns & -7.385 & 0.197 & 0.063 & Decreasing & & ns \\
\hline GSA 11 & 63.572 & 0.390 & 0.058 & -13.226 & 0.372 & $*$ & $-25.227^{\circ}$ & 0.867 & $* * *$ \\
\hline GSA 16 & Decreasing & & & & & & -4.700 & 0.167 & 0.272 \\
\hline GSA 17 & 9.617 & -0.054 & 0.467 & -6.822 & 0.360 & $*$ & Decreasing & & ns \\
\hline GSA 18 & 75.448 & 0.644 & $* *$ & -14.548 & 0.581 & $*$ & 29.516 & 0.301 & $*$ \\
\hline GSA 20 & Decreasing & & & & & & Increasing & & \\
\hline GSA 22 & Decreasing & & & & & & Increasing & & \\
\hline GSA 23 & Decreasing & & & & & & Increasing & & \\
\hline
\end{tabular}




\begin{tabular}{|c|c|c|c|c|c|c|c|c|c|c|c|c|}
\hline & \multicolumn{4}{|c|}{ Shelf } & \multicolumn{4}{|c|}{ Shelf-break/upper-slope } & \multicolumn{4}{|c|}{ Lower-slope } \\
\hline & $N_{90}$ & $s$ & $J^{\prime}$ & FE & $N_{90}$ & $s$ & $J^{\prime}$ & FE & $N_{90}$ & $s$ & $J^{\prime}$ & FE \\
\hline GSA 1 & & n.s. & n.s. & & n.s. & n.s. & n.s. & $=$ & n.s. & n.s. & & \\
\hline GSA 5 & n.s. & n.s. & n.s. & & & n.s. & & n.s. & n.s. & n.s. & n.s. & \\
\hline GSA 6 & n.s. & n.s. & n.s. & & n.s. & n.s. & n.s. & n.s. & n.s. & n.s. & n.s. & n.s. \\
\hline GSA 7 & n.s. & n.s. & & & & & & - & - & - & - & \\
\hline GSA 8 & & & n.s. & & n.s. & & & - & n.s. & & & \\
\hline GSA 9 & n.s. & n.s. & n.s. & & n.s. & n.s. & n.s. & n.s. & n.s. & & n.s. & n.s. \\
\hline GSA 10 & n.s. & $z$ & & $\mathrm{n}$. & n.s. & & n.s. & n.s. & n.s. & & n.s. & n.s. \\
\hline GSA 11 & n.s. & n.s. & n.s. & n. & & n.s. & n.s. & & & & & \\
\hline GSA 16 & n.s. & n.s. & & & n.s. & n.s. & n.s. & $\begin{array}{l}- \\
-\end{array}$ & n.s. & & n.s. & n.s. \\
\hline GSA 17 & n.s. & n.s. & n.s. & n.s. & n.s. & & n.s. & & - & - & - & n.s. \\
\hline GSA 18 & n.s. & n.s. & n.s. & & & n.s. & n.s. & & n.s. & & n.s. & \\
\hline GSA 20 & 7 & n.s. & n.s. & & n.s. & $\pi$ n.s. & n.s. & - & - & - & - & \\
\hline GSA 22 & n.s. & n.s. & n.s. & & n.s. & & & - & n.s. & $\mathrm{N}$. & n.s. & \\
\hline GSA 23 & n.s. & n.s. & n.s. & & n.s. & n.s. & & - & - & $\begin{array}{l}- \\
-\end{array}$ & - & \\
\hline
\end{tabular}

Fig. 3. - Trends obtained from linear regression of $N_{90}$, species richness $(S)$, Pielou evenness $\left(J^{\prime}\right)$ and fishing effort (FE) per GSA and depth stratum (shelf, shelf break/upper slope and lower slope). Trends obtained from the analysis are in continuous lines and trends from expert knowledge in discontinuous line and grey background. n.s., non-significant trends; -, no data available. For GSAs 20, 22 and 23 trends of time series 1994-2006 and 1994-2014 are presented. When results of trends differ, trends from 1994-2006 are presented on the left and trends from 1994 to 2014 on the right of the cell.
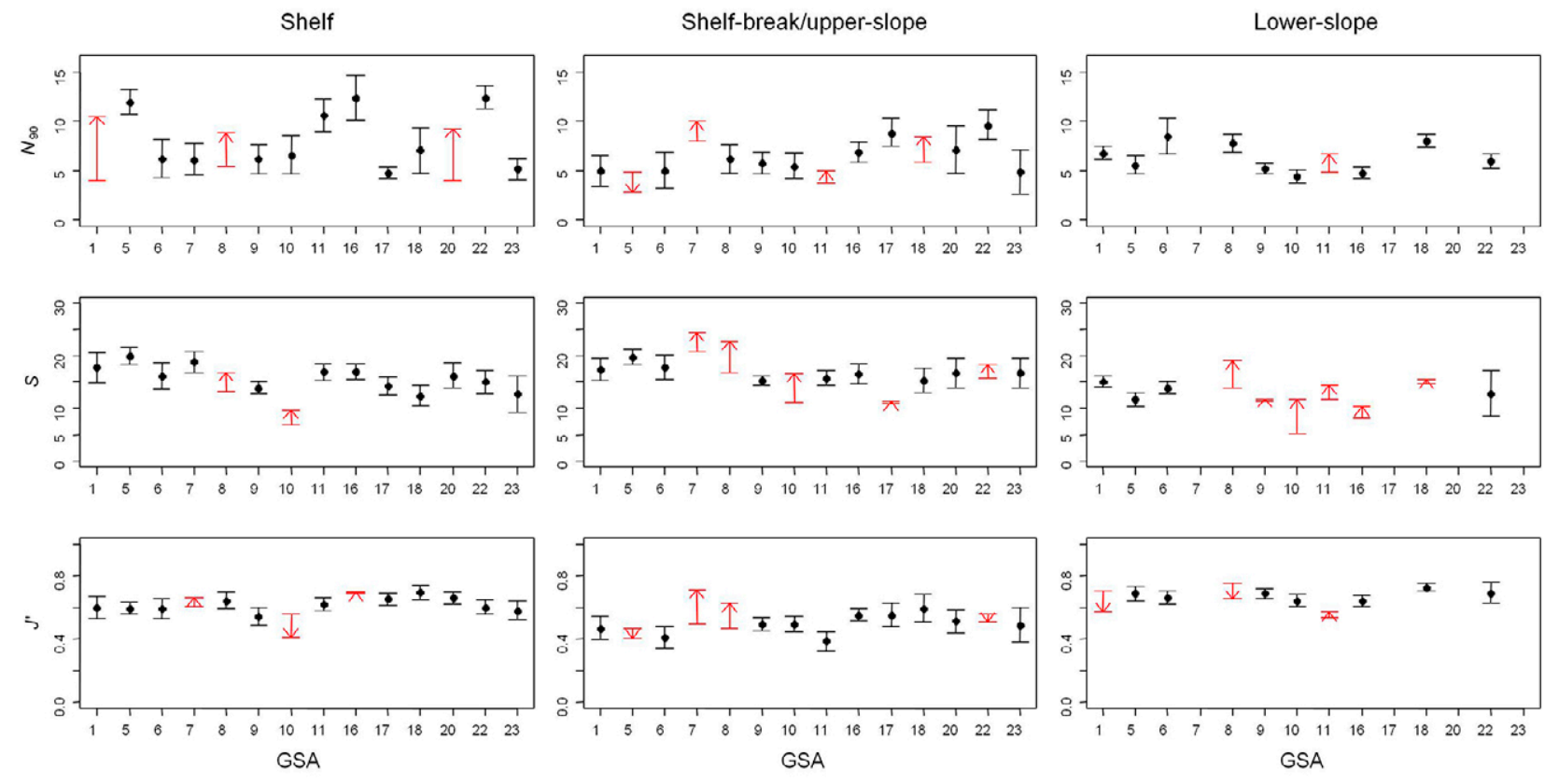

Fig. 4. - Mean values and standard deviations of $N_{90}$, species richness $(S)$ and Pielou evenness $\left(J^{\prime}\right)$ during the whole time series considered for each GSA and depth strata (shelf, shelf break/upper slope and lower slope). In series with a significant temporal trend, values at the beginning and end of the time series are presented in red. Red arrows point to the last value of the time series. For GSAs 20, 22 and 23 the whole time series were taken into account (1994-2014). Note that in some cases the trend of time series does not match the arrow's direction (see Table 2).

effort. Two GSAs showed a decrease in $J$ ' coupled with no trend in fishing effort, while no information on fishing effort trend was available in 3 cases (Tables 3-4, Fig. 3).

\section{Spatial patterns}

Mean values of $N_{90}, S$ and $J$ ' showed differences between GSAs and depth strata (Fig. 4). Regarding 
$N_{90}$, the continental shelf of GSAs 5, 11, 16 and 22 showed higher values than the rest of the GSAs in this depth stratum and even than the shelf break/upper slope and lower slope values. Within the shelf break/ upper slope, the highest values of $N_{90}$ were estimated in GSAs 7, 16, 17, 18, 20 and 22, while on the lower slope the highest values were for GSAs 6, 8 and 18. S showed similar values on the continental shelf of all GSAs, with the exception of GSA 10, which showed a lower value. A similar situation was observed on the shelf break/upper slope, with similar values of $S$ in all GSAs, except for GSA 17 with a lower value, and GSAs 7 and 8, which showed the highest values. On the lower slope, the values of $S$ were similar in all GSAs, with the exception of GSAs 9, 10 and 16, which showed lower values. $J$ ' showed similar values on the continental shelf in all GSAs, except GSAs 9 and 10, which showed lower values. The same scenario was observed on the shelf break/upper slope, with similar values of $J$ ' in all GSAs with the exception of GSAs 1, 5, 6 and 11, which showed lower values. On the lower slope, GSA 11 showed the lowest value of $J$ ', while similar values were obtained in the rest of the GSAs.

The similarity percentage (SIMPER) analysis also showed differences in the species contribution between GSAs and depth strata (Tables 5 and 6). The species with the highest percentage contribution to withingroup similarity on the continental shelf, shelf break/ upper slope and lower slope, respectively, were the following: Serranus hepatus, Gadiculus argenteus and Galeus melastomus in GSA 1; Scyliorhinus canicula, G. argenteus and Phycis blennoides in GSA 5; Merluccius merluccius, Micromesistius poutassou and $P$. blennoides in GSA 6; Mullus barbatus, G. argenteus and G. melastomus in GSA 8; M. merluccius, G. argenteus and P. blennoides in GSA 9; Glossanodon leioglossus, Chlorophthalmus agassizi and Hymenocephalus italicus in GSA 10; S. hepatus, G. leioglossus and $P$. blennoides in GSA $11 ; M$. merluccius, G. argenteus and Nezumia sclerorhynchus in GSA 16; M. merluccius, Helicolenus dactylopterus and P. blennoides in GSA 18; and S. hepatus, Argentina sphyraena and $N$. sclerorhynchus in GSA 22 (Table 5). The species with the highest percentage contribution to within-group similarity were T. minutus on the continental shelf and G. argenteus on the shelf break/upper slope in GSA 7; Lepidotrigla cavillone on the continental shelf and $C$. agassizi on the shelf break/upper slope in GSA 20; and L. cavillone on the continental shelf and A. sphyraena on the shelf break/upper slope in GSA 23. In GSA 17, M. merluccius was the species with the highest contribution on both the continental shelf and the shelf break/ upper slope (Table 5).

Some species showed a high percentage contribution to within-group similarity in most years of the time series and for most of the GSAs (Table 6). On the continental shelf, these species were S. hepatus, $L$. cavillone, M. barbatus and M. merluccius. On the shelf break/upper slope, only G. argenteus was present in all GSAs, while on the lower slope those species were $P$. blennoides, G. melastomus and Etmopterus spinax.

\section{DISCUSSION}

The results have confirmed that demersal fish assemblages are highly structured in the Mediterranean. In fact, we were able to identify three common assemblages in most GSAs corresponding to the continental shelf, shelf break/upper slope and lower slope strata of each area. There were only two GSAs, the northern Adriatic Sea and Crete, that did not present lower slope assemblages, due to the shallower depth surveyed in these areas compared with the rest of GSAs. Although the number of samples was not enough to follow their temporal series, the Gulf of Lions and the eastern Ionian Sea also followed this depth structure. The results confirm the findings of previous works on the structure of demersal assemblages in the Mediterranean, showing that for fishes (Ungaro et al. 1999, Labropoulou and Papaconstantinou 2004, García-Ruiz et al. 2015) and other taxonomic groups (Tserpes et al. 1999, Colloca et al. 2003, Massutí and Reñones 2005) they are strongly organized along a depth gradient.

Despite the similar bathymetric gradient along the Mediterranean, the results showed differences in the bathymetric limitations and composition of demersal fish assemblages between GSAs. This is not surprising considering that oceanographic conditions vary between GSAs, and bathymetric distributions of communities respond according to these variations. In fact, we incorporated cluster analysis to escape from the assumption that communities are structured according to MEDITS strata, and we made an analysis based on real assemblages for each GSA. Therefore, the analysis of demersal fish diversity based on cluster analysis for each particular area of the Mediterranean is more accurate than the assignation of a depth stratum to the samples analysed for the whole Mediterranean, the method that has been generally used up to now.

Our results show a stability and even recovery of demersal fish diversity in the Mediterranean. Of the 114 temporal series analysed, only $27 \%$ showed a significant trend, with an increasing pattern in $71 \%$ of the cases showing significant trends. $N_{90}$ and species richness $(S)$ showed increasing trends in most cases $(87.5 \%$ and $84.6 \%$, respectively), while Pielou evenness $\left(J^{\prime}\right)$ was the indicator that showed the highest proportion of decreasing trends $(60 \%)$. This stability was also shown in the only study analysing long temporal series from bottom trawl survey data (1994-2012) for the whole Mediterranean (Granger et al. 2015). These authors took into account three scales of analysis corresponding to 18 GSAs, 7 biogeographical zones and 2 basins at a depth ranging from 10 to $800 \mathrm{~m}$. The assemblages by depth were not considered, which could explain why they did not detect any recovery.

The continuous increase in fisheries in the last few decades has led to the overexploitation of the main commercial stocks in most Mediterranean areas (Colloca et al. 2013, Sartor et al. 2014). However, bottom trawl fisheries in the Mediterranean have decreased recently, due to the economic losses of this activity (Quetglas et al. 2017; Table 4) and the implementation of additional management measures, such as the prohibition of bot- 
Table 5. - Similarity Percentage analysis (SIMPER) summary table of species appearing in the $90 \%$ cut-off of within-group similarity. A is the mean abundance (individuals $\mathrm{km}^{-2}$ ) of each species, and $\% \mathrm{C}$ is the mean value of the percentage contribution of each species to within-group similarity, taking into account each SIMPER made by group of GSA, depth strata and year. Depth strata are shelf, shelf break/upper slope (SB/US) and lower slope.

\begin{tabular}{|c|c|c|c|c|c|c|c|c|}
\hline GSA 1 Shelf & A & $\% \mathrm{C}$ & GSA 1 SB/US & A & $\% \mathrm{C}$ & GSA 1 Lower slope & A & $\% \mathrm{C}$ \\
\hline Serranus hepatus & 1629 & 31 & Gadiculus argenteus & 7829 & 37 & Galeus melastomus & 2533 & 26 \\
\hline Pagellus acarne & 4684 & 24 & Helicolenus dactylopterus & 2509 & 16 & Nezumia aequalis & 2046 & 22 \\
\hline Merluccius merluccius & 418 & 8 & Micromesistius poutassou & 7519 & 12 & Hoplostethus mediterraneus & 1460 & 15 \\
\hline Cepola macrophthalma & 687 & 6 & Lepidopus caudatus & 6280 & 9 & Coelorinchus caelorhincus & 1315 & 13 \\
\hline Mullus barbatus & 1237 & 6 & Merluccius merluccius & 1217 & 8 & Phycis blennoides & 364 & 8 \\
\hline Callionymus maculatus & 514 & 3 & Phycis blennoides & 706 & 5 & Etmopterus spinax & 245 & 3 \\
\hline Arnoglossus laterna & 237 & 3 & Scyliorhinus canicula & 491 & 3 & Trachyrincus scabrus & 744 & 2 \\
\hline Serranus cabrilla & 338 & 2 & Coelorinchus caelorhincus & 873 & 2 & Micromesistius poutassou & 299 & 2 \\
\hline Arnoglossus thori & 544 & 2 & & & & & & \\
\hline Scyliorhinus canicula & 158 & 2 & & & & & & \\
\hline Lesueurigobius sanzi & 255 & 1 & & & & & & \\
\hline Trachinus draco & 103 & 1 & & & & & & \\
\hline GSA 5 Shelf & & & GSA 5 SB/US & & & GSA 5 Lower slope & & \\
\hline Scyliorhinus canicula & 1348 & 25 & Gadiculus argenteus & 24060 & 68 & Phycis blennoides & 425 & 30 \\
\hline Serranus hepatus & 1464 & 12 & Galeus melastomus & 2222 & 9 & Galeus melastomиs & 440 & 24 \\
\hline Serranus cabrilla & 743 & 11 & Coelorinchus caelorhincus & 1592 & 5 & Nezumia aequalis & 226 & 19 \\
\hline Trachinus draco & 548 & 9 & Chlorophthalmus agassizi & 2906 & 5 & Hymenocephalus italicus & 174 & 7 \\
\hline Mullus surmuletus & 1163 & 6 & Phycis blennoides & 461 & 3 & Notacanthus bonaparte & 55 & 4 \\
\hline Lepidotrigla cavillone & 741 & 5 & Helicolenus dactylopterus & 506 & 3 & Lepidion lepidion & 93 & 4 \\
\hline Merluccius merluccius & 1007 & 5 & & & & Symphurus ligulatus & 45 & 3 \\
\hline Glossanodon leioglossus & 28236 & 5 & & & & & & \\
\hline Chelidonichthys cuculus & 893 & 5 & & & & & & \\
\hline Trigloporus lastoviza & 448 & 4 & & & & & & \\
\hline Scorpaena notata & 163 & 1 & & & & & & \\
\hline Pagellus erythrinus & 179 & 1 & & & & & & \\
\hline Mullus barbatus & 312 & 1 & & & & & & \\
\hline GSA 6 Shelf & & & GSA 6 SB/US & & & GSA 6 Lower slope & & \\
\hline Merluccius merluccius & 2955 & 45 & Micromesistius poutassou & 57532 & 40 & Phycis blennoides & 698 & 43 \\
\hline Trisopterus minutus & 2248 & 19 & Gadiculus argenteus & 9766 & 20 & Galeus melastomus & 381 & 22 \\
\hline Cepola macrophthalma & 514 & 7 & Merluccius merluccius & 4285 & 19 & Micromesistius poutassou & 300 & 4 \\
\hline Mullus barbatus & 487 & 7 & Trisopterus minutus & 1754 & 6 & Nezumia aequalis & 79 & 4 \\
\hline Serranus hepatus & 408 & 7 & Helicolenus dactylopterus & 914 & 3 & Trachyrincus scabrus & 166 & 4 \\
\hline Lepidotrigla cavillone & 250 & 3 & Scyliorhinus canicula & 811 & 3 & Hymenocephalus italicus & 55 & 3 \\
\hline Pagellus erythrinus & 98 & 1 & & & & Gadiculus argenteus & 422 & 3 \\
\hline \multirow[t]{4}{*}{ Lophius budegassa } & 56 & 1 & & & & Symphurus nigrescens & 67 & 2 \\
\hline & & & & & & Scyliorhinus canicula & 130 & 2 \\
\hline & & & & & & Coelorinchus caelorhincus & 128 & 2 \\
\hline & & & & & & Gaidropsarus biscayensis & 58 & 2 \\
\hline
\end{tabular}

\begin{tabular}{|c|c|c|c|c|c|c|c|c|}
\hline GSA 7 Shelf & & & GSA 7 SB/US & & & GSA 7 Lower slope & & \\
\hline $\begin{array}{l}\text { Trisopterus minutus } \\
\text { Merluccius merluccius } \\
\text { Eutrigla gurnardus } \\
\text { Serranus hepatus } \\
\text { Lepidotrigla cavillone } \\
\text { Cepola macrophthalma } \\
\text { Lesueurigobius friesii }\end{array}$ & $\begin{array}{c}6435 \\
3239 \\
1651 \\
896 \\
1297 \\
561 \\
513\end{array}$ & $\begin{array}{l}47 \\
19 \\
12 \\
5 \\
4 \\
2 \\
2\end{array}$ & $\begin{array}{l}\text { Gadiculus argenteus } \\
\text { Galeus melastomus } \\
\text { Micromesistius poutassou } \\
\text { Phycis blennoides } \\
\text { Coelorinchus caelorhincus } \\
\text { Helicolenus dactylopterus } \\
\text { Lepidorhombus boscii } \\
\text { Trigla lyra }\end{array}$ & $\begin{array}{c}6804 \\
1470 \\
7815 \\
561 \\
1068 \\
719 \\
417 \\
565\end{array}$ & $\begin{array}{l}39 \\
11 \\
10 \\
8 \\
7 \\
7 \\
6 \\
5\end{array}$ & & & \\
\hline GSA 8 Shelf & & & GSA $8 \mathrm{SB} / \mathrm{US}$ & & & GSA 8 Lower slope & & \\
\hline $\begin{array}{l}\text { Mullus barbatus } \\
\text { Lepidotrigla cavillone } \\
\text { Scyliorhinus canicula } \\
\text { Serranus hepatus } \\
\text { Pagellus erythrinus } \\
\text { Chelidonichthys cuculus } \\
\text { Serranus cabrilla } \\
\text { Mullus surmuletus } \\
\text { Trigloporus lastoviza } \\
\text { Lepidotrigla dieuzeidei } \\
\end{array}$ & $\begin{array}{c}4127 \\
1287 \\
941 \\
1157 \\
538 \\
352 \\
283 \\
373 \\
162 \\
432 \\
\end{array}$ & $\begin{array}{l}20 \\
19 \\
15 \\
14 \\
10 \\
5 \\
3 \\
2 \\
1 \\
1\end{array}$ & $\begin{array}{l}\text { Gadiculus argenteus } \\
\text { Galeus melastomus } \\
\text { Chlorophthalmus agassizi } \\
\text { Micromesistius poutassou } \\
\text { Scyliorhinus canicula } \\
\text { Lepidotrigla dieuzeidei } \\
\text { Argentina sphyraena }\end{array}$ & $\begin{array}{c}17009 \\
2979 \\
4386 \\
2373 \\
1119 \\
1147 \\
842\end{array}$ & $\begin{array}{l}47 \\
11 \\
9 \\
8 \\
7 \\
4 \\
3\end{array}$ & $\begin{array}{l}\text { Galeus melastomus } \\
\text { Hymenocephalus italicus } \\
\text { Coelorinchus caelorhincus } \\
\text { Phycis blennoides } \\
\text { Helicolenus dactylopterus } \\
\text { Nezumia sclerorhynchus } \\
\text { Hoplostethus mediterraneus } \\
\text { Etmopterus spinax } \\
\text { Chlorophthalmus agassizi }\end{array}$ & $\begin{array}{l}1246 \\
535 \\
405 \\
248 \\
169 \\
223 \\
254 \\
196 \\
280\end{array}$ & $\begin{array}{l}29 \\
19 \\
12 \\
8 \\
6 \\
6 \\
6 \\
4 \\
4\end{array}$ \\
\hline GSA 9 Shelf & & & GSA 9 SB/US & & & GSA 9 Lower slope & & \\
\hline $\begin{array}{l}\text { Merluccius merluccius } \\
\text { Trisopterus minutus } \\
\text { Mullus barbatus } \\
\text { Serranus hepatus } \\
\text { Lepidotrigla cavillone } \\
\text { Arnoglossus laterna } \\
\text { Glossanodon leioglossus }\end{array}$ & $\begin{array}{c}4334 \\
1076 \\
551 \\
274 \\
271 \\
110 \\
4801\end{array}$ & $\begin{array}{l}55 \\
16 \\
8 \\
4 \\
4 \\
3 \\
2\end{array}$ & $\begin{array}{l}\text { Gadiculus argenteus } \\
\text { Merluccius merluccius } \\
\text { Phycis blennoides } \\
\text { Chlorophthalmus agassizi } \\
\text { Galeus melastomus } \\
\text { Micromesistius poutassou }\end{array}$ & $\begin{array}{c}5253 \\
4894 \\
564 \\
896 \\
289 \\
1322\end{array}$ & $\begin{array}{c}52 \\
13 \\
12 \\
6 \\
4 \\
4\end{array}$ & $\begin{array}{l}\text { Phycis blennoides } \\
\text { Hymenocephalus italicus } \\
\text { Galeus melastomus } \\
\text { Nezumia sclerorhynchus } \\
\text { Etmopterus spinax }\end{array}$ & $\begin{array}{l}490 \\
527 \\
439 \\
239 \\
105\end{array}$ & $\begin{array}{c}27 \\
27 \\
22 \\
9 \\
7\end{array}$ \\
\hline
\end{tabular}


Table 5 (Cont.). - Similarity Percentage analysis (SIMPER) summary table of species appearing in the $90 \%$ cut-off of within-group similarity. A is the mean abundance (individuals $\mathrm{km}^{-2}$ ) of each species, and $\% \mathrm{C}$ is the mean value of the percentage contribution of each species to within-group similarity, taking into account each SIMPER made by group of GSA, depth strata and year. Depth strata are shelf, shelf break/ upper slope (SB/US) and lower slope.

\begin{tabular}{|c|c|c|c|c|c|c|c|c|}
\hline GSA 10 Shelf & A & $\% \mathrm{C}$ & GSA 10 SB/US & A & $\% \mathrm{C}$ & GSA 10 Lower slope & A & $\% \mathrm{C}$ \\
\hline $\begin{array}{l}\text { Glossanodon leioglossus } \\
\text { Merluccius merluccius } \\
\text { Lepidotrigla cavillone } \\
\text { Mullus barbatus } \\
\text { Serranus hepatus } \\
\text { Lepidopus caudatus } \\
\text { Trisopterus minutus } \\
\text { Cepola macrophthalma } \\
\text { Arnoglossus laterna }\end{array}$ & $\begin{array}{l}16087 \\
2725 \\
598 \\
502 \\
490 \\
463 \\
236 \\
91 \\
80\end{array}$ & $\begin{array}{l}12 \\
57 \\
3 \\
7 \\
4 \\
2 \\
2 \\
3 \\
2\end{array}$ & $\begin{array}{l}\text { Chlorophthalmus agassizi } \\
\text { Phycis blennoides } \\
\text { Hymenocephalus italicus } \\
\text { Gadiculus argenteus } \\
\text { Merluccius merluccius } \\
\text { Helicolenus dactylopterus }\end{array}$ & $\begin{array}{c}11376 \\
479 \\
1128 \\
1290 \\
1039 \\
226\end{array}$ & $\begin{array}{l}61 \\
8 \\
7 \\
7 \\
6 \\
2\end{array}$ & $\begin{array}{l}\text { Hymenocephalus italicus } \\
\text { Nezumia sclerorhynchus } \\
\text { Phycis blennoides } \\
\text { Galeus melastomus } \\
\text { Etmopterus spinax }\end{array}$ & $\begin{array}{l}1152 \\
351 \\
199 \\
255 \\
70\end{array}$ & $\begin{array}{c}49 \\
19 \\
11 \\
10 \\
4\end{array}$ \\
\hline GSA 11 Shelf & & & GSA 11 SB/US & & & GSA 11 Lower slope & & \\
\hline $\begin{array}{l}\text { Serranus hepatus } \\
\text { Merluccius merluccius } \\
\text { Lepidotrigla cavillone } \\
\text { Trisopterus minutus } \\
\text { Mullus barbatus } \\
\text { Serranus cabrilla } \\
\text { Chelidonichthys cuculus } \\
\text { Scyliorhinus canicula } \\
\text { Mullus surmuletus } \\
\text { Trigloporus lastoviza } \\
\text { Trachinus draco } \\
\text { Argentina sphyraena } \\
\text { Citharus linguatula }\end{array}$ & $\begin{array}{c}1751 \\
2903 \\
1131 \\
2474 \\
840 \\
344 \\
368 \\
335 \\
200 \\
191 \\
105 \\
2800 \\
227\end{array}$ & $\begin{array}{l}26 \\
22 \\
9 \\
9 \\
7 \\
4 \\
3 \\
3 \\
2 \\
2 \\
2 \\
2 \\
1\end{array}$ & $\begin{array}{l}\text { Glossanodon leioglossus } \\
\text { Merluccius merluccius } \\
\text { Trisopterus minutus } \\
\text { Argentina sphyraena } \\
\text { Lepidotrigla dieuzeidei } \\
\text { Scyliorhinus canicula }\end{array}$ & $\begin{array}{l}77021 \\
6301 \\
5084 \\
4673 \\
1590 \\
1175\end{array}$ & $\begin{array}{c}51 \\
13 \\
11 \\
9 \\
5 \\
4\end{array}$ & $\begin{array}{l}\text { Phycis blennoides } \\
\text { Hymenocephalus italicus } \\
\text { Gadiculus argenteus } \\
\text { Galeus melastomus } \\
\text { Chlorophthalmus agassizi } \\
\text { Etmopterus spinax } \\
\text { Merluccius merluccius }\end{array}$ & $\begin{array}{c}879 \\
818 \\
8361 \\
987 \\
3734 \\
122 \\
848\end{array}$ & $\begin{array}{l}31 \\
20 \\
18 \\
12 \\
5 \\
3 \\
2\end{array}$ \\
\hline GSA 16 Shelf & & & GSA 16 SB/US & & & GSA 16 Lower slope & & \\
\hline $\begin{array}{l}\text { Merluccius merluccius } \\
\text { Serranus hepatus } \\
\text { Lepidotrigla cavillone } \\
\text { Chelidonichthys cuculus } \\
\text { Mullus barbatus } \\
\text { Mullus surmuletus } \\
\text { Raja miraletus } \\
\text { Serranus cabrilla } \\
\text { Citharus linguatula } \\
\text { Argentina sphyraena } \\
\text { Trisopterus minutus } \\
\text { Trigloporus lastoviza } \\
\text { Arnoglossus laterna } \\
\text { Lepidotrigla dieuzeidei } \\
\text { Scyliorhinus canicula } \\
\text { Zeus faber } \\
\text { Trachinus draco }\end{array}$ & $\begin{array}{l}970 \\
785 \\
1327 \\
548 \\
580 \\
261 \\
302 \\
181 \\
234 \\
912 \\
280 \\
131 \\
116 \\
588 \\
102 \\
52 \\
77\end{array}$ & $\begin{array}{l}25 \\
11 \\
10 \\
7 \\
7 \\
5 \\
5 \\
4 \\
3 \\
2 \\
2 \\
2 \\
2 \\
2 \\
2 \\
2 \\
1\end{array}$ & $\begin{array}{l}\text { Gadiculus argenteus } \\
\text { Merluccius merluccius } \\
\text { Chlorophthalmus agassizi } \\
\text { Coelorinchus caelorhincus } \\
\text { Hymenocephalus italicus } \\
\text { Phycis blennoides } \\
\text { Lepidopus caudatus }\end{array}$ & $\begin{array}{c}5100 \\
1622 \\
3368 \\
1231 \\
768 \\
314 \\
2220\end{array}$ & $\begin{array}{l}26 \\
20 \\
14 \\
10 \\
8 \\
7 \\
6\end{array}$ & $\begin{array}{l}\text { Nezumia sclerorhynchus } \\
\text { Hymenocephalus italicus } \\
\text { Galeus melastomus } \\
\text { Nezumia aequalis } \\
\text { Hoplostethus mediterraneus } \\
\text { Phycis blennoides }\end{array}$ & $\begin{array}{c}982 \\
573 \\
318 \\
383 \\
134 \\
79\end{array}$ & $\begin{array}{l}40 \\
19 \\
17 \\
7 \\
5 \\
3\end{array}$ \\
\hline GSA 17 Shelf & & & GSA 17 SB/US & & & GSA 17 Lower slope & & \\
\hline $\begin{array}{l}\text { Merluccius merluccius } \\
\text { Mullus barbatus } \\
\text { Trisopterus minutus } \\
\text { Serranus hepatus } \\
\text { Cepola macrophthalma } \\
\text { Lepidotrigla cavillone } \\
\text { Merlangius merlangus } \\
\text { Eutrigla gurnardus } \\
\end{array}$ & $\begin{array}{c}931 \\
1344 \\
861 \\
1150 \\
327 \\
359 \\
161 \\
108 \\
\end{array}$ & $\begin{array}{l}28 \\
20 \\
18 \\
13 \\
6 \\
2 \\
2 \\
2 \\
\end{array}$ & $\begin{array}{l}\text { Merluccius merluccius } \\
\text { Micromesistius poutassou } \\
\text { Trisopterus minutus } \\
\text { Lepidopus caudatus } \\
\text { Gadiculus argenteus } \\
\text { Lesueurigobius friesii }\end{array}$ & $\begin{array}{l}2155 \\
3434 \\
312 \\
489 \\
379 \\
201\end{array}$ & $\begin{array}{c}43 \\
33 \\
5 \\
5 \\
3 \\
2\end{array}$ & & & \\
\hline GSA 18 Shelf & & & GSA 18 SB/US & & & GSA 18 Lower slope & & \\
\hline $\begin{array}{l}\text { Merluccius merluccius } \\
\text { Trisopterus minutus } \\
\text { Mullus barbatus } \\
\text { Serranus hepatus } \\
\text { Lepidotrigla cavillone } \\
\text { Chelidonichthys cuculus } \\
\text { Arnoglossus laterna } \\
\text { Cepola macrophthalma } \\
\text { Lesueurigobius friesii }\end{array}$ & $\begin{array}{c}939 \\
424 \\
317 \\
175 \\
376 \\
232 \\
106 \\
81 \\
74\end{array}$ & $\begin{array}{l}43 \\
20 \\
7 \\
6 \\
4 \\
4 \\
3 \\
2 \\
2\end{array}$ & $\begin{array}{l}\text { Helicolenus dactylopterus } \\
\text { Chlorophthalmus agassizi } \\
\text { Micromesistius poutassou } \\
\text { Glossanodon leioglossus } \\
\text { Argentina sphyraena } \\
\text { Lepidopus caudatus } \\
\text { Gadiculus argenteus } \\
\text { Phycis blennoides } \\
\text { Chelidonichthys cuculus } \\
\text { Scyliorhinus canicula } \\
\text { Lepidorhombus boscii } \\
\text { Arnoglossus rueppelii } \\
\text { Lepidotrigla cavillone } \\
\text { Merluccius merluccius }\end{array}$ & $\begin{array}{c}466 \\
663 \\
823 \\
2993 \\
1378 \\
338 \\
587 \\
109 \\
470 \\
146 \\
65 \\
153 \\
238 \\
895\end{array}$ & $\begin{array}{l}11 \\
10 \\
8 \\
7 \\
6 \\
4 \\
4 \\
4 \\
4 \\
3 \\
2 \\
2 \\
2 \\
25\end{array}$ & $\begin{array}{l}\text { Phycis blennoides } \\
\text { Nezumia sclerorhynchus } \\
\text { Galeus melastomus } \\
\text { Hoplostethus mediterraneus } \\
\text { Coelorinchus caelorhincus } \\
\text { Hymenocephalus italicus } \\
\text { Etmopterus spinax } \\
\text { Helicolenus dactylopterus }\end{array}$ & $\begin{array}{l}405 \\
305 \\
282 \\
319 \\
318 \\
254 \\
167 \\
117\end{array}$ & $\begin{array}{l}20 \\
14 \\
13 \\
11 \\
10 \\
10 \\
9 \\
4\end{array}$ \\
\hline
\end{tabular}


Table 5 (Cont.). - Similarity Percentage analysis (SIMPER) summary table of species appearing in the $90 \%$ cut-off of within-group similarity. A is the mean abundance (individuals $\mathrm{km}^{-2}$ ) of each species, and \% $\mathrm{C}$ is the mean value of the percentage contribution of each species to within-group similarity, taking into account each SIMPER made by group of GSA, depth strata and year. Depth strata are shelf, shelf break/ upper slope (SB/US) and lower slope.

\begin{tabular}{|c|c|c|c|c|c|c|c|c|}
\hline GSA 20 Shelf & A & $\% \mathrm{C}$ & GSA 20 SB/US & A & $\% \mathrm{C}$ & GSA 20 Lower slope & A & $\% \mathrm{C}$ \\
\hline Lepidotrigla cavillone & 1299 & 26 & Chlorophthalmus agassizi & 6565 & 28 & & & \\
\hline Serranus hepatus & 1416 & 24 & Gadiculus argenteus & 9073 & 24 & & & \\
\hline Mullus barbatus & 1145 & 15 & Argentina sphyraena & 3257 & 14 & & & \\
\hline Merluccius merluccius & 527 & 11 & Merluccius merluccius & 860 & 6 & & & \\
\hline Arnoglossus laterna & 329 & 5 & Lepidopus caudatus & 444 & 4 & & & \\
\hline Trisopterus minutus & 359 & 3 & Helicolenus dactylopterus & 361 & 4 & & & \\
\hline Pagellus erythrinus & 272 & 2 & Scyliorhinus canicula & 187 & 3 & & & \\
\hline Argentina sphyraena & 2318 & 2 & Peristedion cataphractum & 714 & 2 & & & \\
\hline \multirow[t]{3}{*}{ Citharus linguatula } & 142 & 2 & Coelorinchus caelorhincus & 588 & 2 & & & \\
\hline & & & Hymenocephalus italicus & 677 & 2 & & & \\
\hline & & & Phycis blennoides & 129 & 2 & & & \\
\hline \multicolumn{2}{|l|}{ GSA 22 Shelf } & & \multicolumn{2}{|l|}{ GSA 22 SB/US } & & \multicolumn{3}{|l|}{ GSA 22 Lower slope } \\
\hline Serranus hepatus & 1774 & 19 & Argentina sphyraena & 12691 & 27 & Nezumia sclerorhynchus & 626 & 43 \\
\hline Trisopterus minutus & 1666 & 13 & Gadiculus argenteus & 5823 & 18 & Hymenocephalus italicus & 575 & 14 \\
\hline Merluccius merluccius & 1890 & 11 & Merluccius merluccius & 505 & 10 & Trachyrincus scabrus & 251 & 9 \\
\hline Citharus linguatula & 569 & 11 & Micromesistius poutassou & 2037 & 7 & Phycis blennoides & 119 & 8 \\
\hline Lepidotrigla cavillone & 887 & 10 & Chlorophthalmus agassizi & 5423 & 6 & Coelorinchus caelorhincus & 317 & 8 \\
\hline Mullus barbatus & 785 & 5 & Phycis blennoides & 169 & 5 & Hoplostethus mediterraneus & 105 & 6 \\
\hline Chelidonichthys cuculus & 968 & 4 & Scyliorhinus canicula & 372 & 5 & Etmopterus spinax & 66 & 4 \\
\hline Lophius budegassa & 178 & 4 & Lepidorhombus boscii & 151 & 4 & & & \\
\hline Argentina sphyraena & 3244 & 4 & Coelorinchus caelorhincus & 1395 & 4 & & & \\
\hline Serranus cabrilla & 221 & 3 & Hymenocephalus italicus & 801 & 3 & & & \\
\hline Scyliorhinus canicula & 195 & 3 & Helicolenus dactylopterus & 148 & 2 & & & \\
\hline Arnoglossus laterna & 164 & 2 & Lepidopus caudatus & 431 & 2 & & & \\
\hline Dentex maroccanus & 458 & 2 & & & & & & \\
\hline Mullus surmuletus & 246 & 1 & & & & & & \\
\hline \multicolumn{2}{|l|}{ GSA 23 Shelf } & & \multicolumn{2}{|l|}{ GSA 23 SB/US } & & \multicolumn{3}{|l|}{ GSA 23 Lower slope } \\
\hline Lepidotrigla cavillone & 2773 & 38 & Argentina sphyraena & 16100 & 49 & & & \\
\hline Mullus barbatus & 3330 & 21 & Chlorophthalmus agassizi & 9753 & 10 & & & \\
\hline Serranus hepatus & 2784 & 12 & Merluccius merluccius & 1305 & 9 & & & \\
\hline Citharus linguatula & 262 & 7 & Chelidonichthys cuculus & 758 & 6 & & & \\
\hline Pagellus erythrinus & 627 & 6 & Coelorinchus caelorhincus & 657 & 6 & & & \\
\hline Arnoglossus laterna & 855 & 4 & Helicolenus dactylopterus & 330 & 5 & & & \\
\hline \multirow[t]{3}{*}{ Serranus cabrilla } & 263 & 3 & Lepidotrigla cavillone & 400 & 2 & & & \\
\hline & & & Phycis blennoides & 109 & 2 & & & \\
\hline & & & Gadiculus argenteus & 3003 & 2 & & & \\
\hline
\end{tabular}

tom trawling within 1.5 nautical miles of the coast (EC Regulation 1967/2006). However, this recent measure has possibly displaced part of the trawl fishing effort from the shelf to deeper bathymetric zones (Tserpes et al. 2011). Our results show that increasing trends in $N_{90}$ and $S$ and decreasing trends in $J$ ' coincide in some cases with decreasing trends in bottom trawl fishing effort. There could therefore be a cause and effect relation, because it is in accordance with the expected effect of fishing on biodiversity. The increasing trend in $N_{90}$ with decreasing fishing effort reinforces the previous results that confirm the usefulness of this index for detecting the effects of fishing on demersal fish diversity. The increase of evenness with increasing fishing effort has been suggested by some authors (Murawski 2000, Zhou et al. 2010) due to the reduction of dominant species by fishing (Cury et al. 2000, Rice 2000) and has been confirmed by the study of the effects of fishing on evenness indices (D'Onghia et al. 2003, Farriols et al. 2017). However, the expected increase in $S$ and decrease in $J$ ' with decreasing fishing effort are not always observed in our results. There are some differences in the aspects of diversity that each of these indices capture. Increasing $N_{90}$ values with decreasing fishing effort indicate an increase in the frequency of occurrence and the evenness of the distribution of species abundances due to expan- sion to areas with the most favourable environmental conditions. On the other hand, an increase in $S$ and a decrease in $J$ ' with decreasing fishing effort implies an increase in the number of species and an increase in the dominance of some species, respectively. Although both number of species and evenness are also affecting $N_{90}$, the calculation of each of these indices is extremely different. $N_{90}$ takes into account the homogeneity or heterogeneity of all the samples of a stratum and year for each GSA in its calculation and involves the most frequent and abundant species in the group without losing species identity through the comparison among all the samples in the group. In contrast, $S$ and $J$ ' in a group are calculated from their mean values and consequently species identity is lost. This may explain why extreme values of fishing effort were needed to detect the effects of fishing in $S$ and $J$ ' in previous works (Farriols et al. 2017). In some cases, $N_{90}$ showed no trend when there was a trend in fishing effort and viceversa. This finding could be due to several causes. It is either too early to detect the effects of decreasing fishing effort on demersal fish diversity or the decrease is not sufficiently important to change the diversity trend. Similarly, increasing trends in fishing effort could not result in a decrease in fish diversity due to the adaptation of demersal fish communities to fishing exploitation. 
Table 6. - Number of years that each species contributed to the $90 \%$ cut-off of within-group similarity, taking into account each similarity percentage analysis (SIMPER) by GSA, depth stratum and year during the time series. Depth strata are shelf, shelf break/upper slope (SB/ US) and lower slope.

\begin{tabular}{|c|c|c|c|c|c|c|c|c|c|c|c|c|c|c|c|}
\hline \multirow[b]{2}{*}{ Stratum } & \multirow{2}{*}{ Species } & \multicolumn{14}{|c|}{ GSA } \\
\hline & & 1 & 5 & 6 & 7 & 8 & 9 & 10 & 11 & 16 & 17 & 18 & 20 & 22 & 23 \\
\hline \multirow[t]{52}{*}{ Shelf } & Argentina sphyraena & - & - & - & - & 3 & 4 & 1 & 9 & 13 & - & 2 & 9 & 6 & - \\
\hline & Arnoglossus imperialis & - & - & - & - & - & - & - & - & 4 & - & - & - & - & - \\
\hline & Arnoglossus laterna & 8 & - & 3 & 6 & - & 12 & 10 & - & 10 & 4 & 12 & 11 & 8 & 4 \\
\hline & Arnoglossus rueppelii & - & 2 & - & - & - & - & - & - & - & - & - & - & - & - \\
\hline & Arnoglossus thori & 7 & 3 & - & - & 5 & - & - & 6 & 4 & - & - & - & - & - \\
\hline & Callionymus maculatus & 12 & - & 1 & 2 & - & - & - & - & - & 2 & 3 & - & - & - \\
\hline & Cepola macrophthalma & 16 & - & 18 & 11 & - & 4 & 13 & 4 & 1 & 18 & 11 & - & 3 & - \\
\hline & Chelidonichthys cuculus & - & 14 & - & - & 17 & - & 1 & 15 & 19 & 3 & 13 & 7 & 12 & - \\
\hline & Chelidonichthys obscurus & - & - & - & - & - & - & - & - & 7 & - & - & - & - & - \\
\hline & Citharus linguatula & - & - & 2 & 1 & - & 1 & - & 6 & 18 & 1 & - & 4 & 14 & 12 \\
\hline & Deltentosteus collonianus & - & - & - & - & - & - & - & 1 & - & - & - & - & - & - \\
\hline & Deltentosteus quadrimaculatus & 1 & 3 & 1 & - & 4 & - & 1 & 5 & - & - & - & - & - & 2 \\
\hline & Dentex maroccanus & - & - & - & - & - & - & - & - & - & - & - & 1 & 6 & - \\
\hline & Diplodus annularis & - & - & - & - & - & - & - & 1 & - & - & - & 2 & 1 & - \\
\hline & Eutrigla gurnardus & - & - & 1 & 22 & - & - & - & - & - & 5 & 3 & 1 & 3 & - \\
\hline & Glossanodon leioglossus & - & 12 & - & - & - & 8 & 17 & - & - & - & - & - & - & - \\
\hline & Gymnammodytes cicerelus & - & - & - & - & - & - & - & 1 & - & - & - & - & - & - \\
\hline & Helicolenus dactylopterus & - & - & - & - & - & - & 2 & - & - & - & - & - & - & - \\
\hline & Lepidopus caudatus & 1 & - & - & - & - & 1 & 8 & - & 1 & - & 2 & - & - & - \\
\hline & Lepidotrigla cavillone & 4 & 14 & 12 & 18 & 20 & 15 & 16 & 22 & 22 & 9 & 15 & 14 & 14 & 13 \\
\hline & Lepidotrigla dieuzeidei & 1 & - & - & - & 4 & - & - & 1 & 6 & - & - & 3 & 2 & - \\
\hline & Lesueurigobius friesii & - & - & 1 & 7 & - & 4 & 1 & - & - & 2 & 6 & - & 3 & - \\
\hline & Lesueurigobius sanzi & 6 & - & 1 & - & - & - & - & - & - & - & - & - & - & - \\
\hline & Lesueurigobius suerii & - & - & - & - & - & - & 4 & - & - & - & - & - & - & - \\
\hline & Lophius budegassa & - & - & 6 & 2 & - & - & - & - & - & 2 & 6 & - & 14 & 1 \\
\hline & Merlangius merlangus & - & - & - & - & - & - & - & - & - & 10 & - & - & - & - \\
\hline & Merluccius merluccius & 21 & 14 & 22 & 22 & 2 & 22 & 22 & 22 & 22 & 22 & 22 & 13 & 14 & 1 \\
\hline & Microchirus boscanion & 1 & - & - & - & - & - & - & - & - & - & - & - & - & - \\
\hline & Micromesistius poutassou & - & - & - & 1 & - & - & - & - & - & - & 3 & - & - & - \\
\hline & Mullus barbatus & 17 & 4 & 20 & 2 & 20 & 21 & 20 & 22 & 19 & 22 & 17 & 14 & 14 & 13 \\
\hline & Mullus surmuletus & - & 14 & - & - & 7 & - & - & 10 & 17 & - & - & - & 4 & 1 \\
\hline & Ophichthus rufus & 2 & - & 2 & - & - & - & - & - & - & - & - & - & - & - \\
\hline & Pagellus acarne & 21 & - & 2 & - & 2 & - & - & - & 1 & - & - & - & - & 4 \\
\hline & Pagellus bogaraveo & 5 & - & - & - & - & - & - & - & - & - & - & - & - & - \\
\hline & Pagellus erythrinus & 3 & 5 & 3 & - & 21 & - & 5 & 3 & 4 & 2 & - & 8 & - & 12 \\
\hline & Phycis blennoides & - & - & - & - & - & - & 3 & - & - & - & 1 & - & - & - \\
\hline & Pomatoschistus marmoratus & 1 & - & - & - & - & - & - & - & - & - & - & - & - & - \\
\hline & Pomatoschistus microps & 1 & - & - & - & - & - & - & - & - & - & - & - & - & - \\
\hline & Raja clavata & - & 2 & - & - & - & - & - & - & - & - & - & - & 2 & - \\
\hline & Raja miraletus & - & - & - & - & 4 & - & - & 2 & 22 & - & - & - & - & - \\
\hline & Scorpaena notata & 1 & 4 & - & - & - & - & - & 2 & - & - & - & - & - & - \\
\hline & Scorpaena scrofa & - & 3 & - & - & - & - & - & - & - & - & - & - & - & - \\
\hline & Scyliorhinus canicula & 5 & 14 & - & - & 21 & - & - & 15 & 12 & - & - & - & 12 & - \\
\hline & Serranus cabrilla & 10 & 14 & - & - & 13 & - & - & 20 & 21 & - & - & 2 & 14 & 4 \\
\hline & Serranus hepatus & 22 & 14 & 20 & 20 & 20 & 22 & 18 & 22 & 21 & 22 & 18 & 13 & 14 & 5 \\
\hline & Symphurus nigrescens & 2 & - & 1 & - & - & - & - & - & - & - & 1 & - & 2 & - \\
\hline & Trachinus draco & 6 & 14 & - & - & - & - & - & 12 & 8 & - & - & - & - & - \\
\hline & Trigloporus lastoviza & - & 14 & - & - & 2 & - & - & 11 & 11 & - & - & - & - & - \\
\hline & Trisopterus luscus & - & - & 1 & - & - & - & - & - & - & - & - & - & - & - \\
\hline & Trisopterus minutus & - & 2 & 20 & 22 & - & 22 & 6 & 22 & 5 & 22 & 22 & 7 & 14 & - \\
\hline & Uranoscopus scaber & - & - & - & - & - & - & - & - & 3 & - & - & - & - & - \\
\hline & Zeus faber & - & 3 & - & - & 1 & - & - & 1 & 10 & - & - & 1 & - & - \\
\hline SB/US & Argentina sphyraena & - & - & 6 & 3 & 10 & 3 & - & 19 & 5 & - & 6 & 12 & 14 & 14 \\
\hline & Arnoglossus rueppelii & 1 & - & 2 & - & - & - & - & - & - & - & 10 & - & - & 1 \\
\hline & Callionymus maculatus & 2 & - & - & - & - & - & - & - & - & - & - & - & - & - \\
\hline & Cepola macrophthalma & - & - & 1 & - & - & - & - & - & - & 3 & - & - & - & - \\
\hline & Chelidonichthys cuculus & - & - & - & - & 1 & - & - & 1 & - & 1 & 11 & - & 1 & 10 \\
\hline & Chlorophthalmus agassizi & - & 12 & - & 3 & 18 & 18 & 22 & - & 20 & - & 15 & 11 & 8 & 6 \\
\hline & Coelorinchus caelorhincus & 5 & 8 & - & 20 & 4 & 3 & 5 & - & 20 & - & - & 3 & 12 & 2 \\
\hline & Epigonus denticulatus & 1 & - & - & - & - & - & - & - & - & - & - & - & - & - \\
\hline & Epigonus telescopus & - & - & - & - & - & - & - & - & 1 & - & - & - & - & - \\
\hline & Gadiculus argenteus & 21 & 14 & 20 & 22 & 21 & 22 & 19 & 1 & 21 & 8 & 6 & 12 & 13 & 5 \\
\hline & Galeorhinus galeus & - & - & - & - & - & - & - & - & - & - & - & - & - & 1 \\
\hline & Galeus melastomus & - & 10 & - & 22 & 20 & 15 & 2 & - & - & - & - & 1 & 1 & - \\
\hline & Glossanodon leioglossus & - & - & - & - & 2 & - & - & 22 & - & - & 7 & - & - & - \\
\hline & Helicolenus dactylopterus & 17 & 4 & 11 & 21 & 1 & 7 & 5 & - & 7 & 1 & 22 & 8 & 9 & 5 \\
\hline & Hoplostethus mediterraneus & - & - & - & - & - & - & - & - & - & - & - & 1 & - & 1 \\
\hline & Hymenocephalus italicus & - & 2 & - & - & - & 1 & 19 & - & 20 & - & - & 5 & 11 & 2 \\
\hline & Lepidopus caudatus & 10 & - & 1 & - & - & 1 & 5 & - & 15 & 10 & 5 & 5 & 2 & - \\
\hline & Lepidorhombus boscii & - & 2 & - & 19 & 5 & 1 & - & - & - & - & 7 & 3 & 9 & 2 \\
\hline & Lepidorhombus whiffiagonis & - & - & - & - & - & - & - & - & - & 1 & 1 & - & - & - \\
\hline & Lepidotrigla cavillone & - & - & - & - & - & - & - & - & - & - & 2 & - & - & 3 \\
\hline & Lepidotrigla dieuzeidei & - & - & - & - & 9 & - & - & 9 & - & - & 3 & 3 & 1 & 1 \\
\hline
\end{tabular}


Table 6 (Cont.). - Number of years that each species contributed to the $90 \%$ cut-off of within-group similarity, taking into account each similarity percentage analysis (SIMPER) by GSA, depth stratum and year during the time series. Depth strata are shelf, shelf break/upper slope (SB/US) and lower slope.

\begin{tabular}{|c|c|c|c|c|c|c|c|c|c|c|c|c|c|c|c|}
\hline \multirow{2}{*}{ Stratum } & \multirow[b]{2}{*}{ Species } & \multicolumn{14}{|c|}{ GSA } \\
\hline & & 1 & 5 & 6 & 7 & 8 & 9 & 10 & 11 & 16 & 17 & 18 & 20 & 22 & 23 \\
\hline \multirow{51}{*}{ Lower slope } & Lesueurigobius friesii & - & - & - & - & - & - & - & - & - & 7 & 2 & - & - & 1 \\
\hline & Lophius budegassa & - & - & 1 & - & - & - & - & - & - & 2 & - & - & 2 & 1 \\
\hline & Merluccius merluccius & 15 & - & 22 & 2 & 4 & 22 & 18 & 21 & 22 & 22 & 22 & 10 & 14 & 10 \\
\hline & Micromesistius poutassou & 10 & 4 & 22 & 21 & 18 & 11 & 3 & 2 & - & 22 & 16 & - & 10 & 2 \\
\hline & Mullus barbatus & - & - & 3 & - & - & - & - & - & - & 2 & 7 & - & - & - \\
\hline & Mullus surmuletus & - & - & - & - & - & - & - & - & - & - & - & - & - & 1 \\
\hline & Nezumia sclerorhynchus & - & - & - & - & - & - & - & - & - & - & - & 2 & 1 & - \\
\hline & Pagellus bogaraveo & 5 & - & - & 1 & - & - & - & - & - & - & 1 & - & 2 & - \\
\hline & Peristedion cataphractum & - & - & - & - & - & - & - & - & - & - & 4 & 8 & - & 1 \\
\hline & Phycis blennoides & 9 & 7 & 4 & 22 & 1 & 21 & 22 & - & 21 & 5 & 13 & 4 & 9 & 4 \\
\hline & Scorpaena elongata & 1 & - & - & - & - & - & - & - & - & - & - & - & - & - \\
\hline & Scyliorhinus canicula & 10 & - & 8 & 1 & 20 & - & - & 8 & - & - & 10 & 4 & 13 & - \\
\hline & Serranus hepatus & 3 & - & - & - & - & - & - & - & - & - & - & - & - & - \\
\hline & Symphurus nigrescens & 1 & - & - & - & - & - & 1 & - & - & - & 1 & - & - & - \\
\hline & Synchiropus phaeton & - & 1 & - & 1 & - & - & - & - & - & - & - & - & - & - \\
\hline & Trachyrincus scabrus & - & - & - & 1 & - & - & - & - & - & - & - & - & - & - \\
\hline & Trigla lyra & - & - & - & 14 & 1 & - & - & - & - & - & 2 & - & - & - \\
\hline & Trisopterus minutus & - & - & 12 & - & - & 1 & - & 19 & - & 14 & - & 3 & 4 & - \\
\hline & Zeus faber & - & - & - & - & - & - & - & - & - & - & 1 & - & - & 1 \\
\hline & Alepocephalus rostratus & 1 & - & - & - & - & - & - & - & - & - & - & - & - & - \\
\hline & Argentina sphyraena & - & - & - & - & - & - & - & 1 & - & - & - & - & - & - \\
\hline & Chimaera monstrosa & - & - & - & - & - & - & - & - & 1 & - & 3 & - & 2 & - \\
\hline & Chlorophthalmus agassizi & - & - & - & - & 10 & - & - & 16 & - & - & 6 & - & - & - \\
\hline & Coelorinchus caelorhincus & 22 & - & 9 & - & 21 & - & 1 & - & 7 & - & 21 & - & 10 & - \\
\hline & Epigonus denticulatus & 5 & - & 5 & - & - & - & - & - & - & - & - & - & - & - \\
\hline & Etmopterus spinax & 13 & 7 & 2 & - & 13 & 21 & 7 & 16 & 1 & - & 20 & - & 5 & - \\
\hline & Gadiculus argenteus & 2 & - & 15 & - & 4 & - & - & 22 & - & - & - & - & - & - \\
\hline & Gaidropsarus biscayensis & - & - & 6 & - & - & - & - & - & - & - & - & - & - & - \\
\hline & Galeus melastomus & 22 & 14 & 22 & - & 21 & 22 & 21 & 22 & 22 & - & 22 & - & 2 & - \\
\hline & Glossanodon leioglossus & - & - & - & - & - & - & - & 1 & - & - & - & - & - & - \\
\hline & Helicolenus dactylopterus & 5 & - & 9 & - & 19 & - & - & 7 & 1 & - & 16 & - & - & - \\
\hline & Hoplostethus mediterraneus & 22 & - & 1 & - & 15 & 2 & 4 & - & 17 & - & 21 & - & 7 & - \\
\hline & Hymenocephalus italicus & - & 11 & 13 & - & 21 & 22 & 21 & 22 & 21 & - & 20 & - & 13 & - \\
\hline & Lepidion lepidion & - & 6 & 3 & - & - & - & - & - & - & - & - & - & - & - \\
\hline & Lepidopus caudatus & 1 & - & 1 & - & - & - & - & - & - & - & - & - & - & - \\
\hline & Lepidorhombus boscii & - & - & 3 & - & 1 & - & - & 1 & - & - & - & - & 1 & - \\
\hline & Lophius budegassa & - & - & - & - & - & - & - & - & - & - & - & - & 1 & - \\
\hline & Merluccius merluccius & - & - & - & - & - & - & - & 8 & - & - & 3 & - & 1 & - \\
\hline & Micromesistius poutassou & 6 & - & 20 & - & - & - & - & - & - & - & 1 & - & - & - \\
\hline & Mora moro & - & 3 & - & - & - & - & - & 1 & - & - & - & - & - & - \\
\hline & Nettastoma melanurum & - & - & - & - & - & - & 1 & - & - & - & - & - & - & - \\
\hline & Nezumia aequalis & 22 & 14 & 18 & - & - & 1 & - & - & 3 & - & - & - & - & - \\
\hline & Nezumia sclerorhynchus & - & - & - & - & 16 & 21 & 21 & 4 & 19 & - & 22 & - & 13 & - \\
\hline & Notacanthus bonaparte & - & 5 & 5 & - & - & - & - & - & - & - & - & - & - & - \\
\hline & Pagellus bogaraveo & - & - & 1 & - & 1 & - & - & - & - & - & - & - & - & - \\
\hline & Phycis blennoides & 21 & 14 & 22 & - & 19 & 22 & 22 & 22 & 13 & - & 21 & - & 13 & - \\
\hline & Polyacanthonotus rissoanus & - & 1 & - & - & - & - & - & - & - & - & - & - & - & - \\
\hline & Scyliorhinus canicula & - & - & 12 & - & - & - & - & - & - & - & - & - & - & - \\
\hline & Symphurus ligulatus & - & 3 & 2 & - & - & - & 1 & - & - & - & - & - & - & - \\
\hline & Symphurus nigrescens & - & - & 8 & - & - & - & - & 2 & - & - & - & - & 1 & - \\
\hline & Trachyrincus scabrus & 11 & - & 13 & - & 2 & 3 & - & - & - & - & 1 & - & 9 & - \\
\hline
\end{tabular}

It must also be considered that there is a high complexity in the evaluation of fishing effort in the whole area. Available temporal series used to analyse fishing effort do not cover the whole time series of demersal fish diversity in all cases (see Table S1), and the inclusion of more years of the temporal series to the analysis could lead to different trends of fishing effort. In addition, as the nominal spatio-temporal pattern of fishing effort on a Mediterranean-wide level is not available, the use of different effort estimates in the areas may increase the uncertainty of the model. Moreover, number of fishing vessels is a poor proxy for effort, because does not account for other capacity changes (e.g. length overall, or kilowatts), because it does not account for technological creep and or temporal and spatial changes of fishing operations (Anticamara et al. 2011). For instance, though the regulation decreasing fishing capacity has been in place since 1991, the gross tonnage of the fleets may be increasing because boats are decreasing in number (decommissioning) but increasing in size over time (e.g. Fortibuoni et al. 2017) or because vessels have increased trawling time. This issue is enormously relevant for the Mediterranean Sea, where fisheries are managed by effort control and technical measures in contrast to quotas (northern EU seas; see Cardinale and Scarcella 2017) and should be considered when the results are interpreted. However, in the Spanish and French Mediterranean, restrictions on hours of trawling would not permit an unlimited increase in fishing effort with a decreasing number of vessels (REAL DECRETO 1440/1999, de 10 de septiembre; Arrêté n 99-162 du 10 juin 1999). 
In any case, a more appropriate indicator than number of vessels should be used for fishing effort whenever possible.

Regarding spatial patterns, we did not find the expected longitudinal decreasing west-east pattern in species richness observed in previous works on fish communities (Quignard and Tomasini 2000, Coll et al. 2010). Nor was this trend observed for $N_{90}$ and $J$ ' in any depth stratum. The absence of a western/eastern decreasing trend further suggests that primary production or temperature regime are possibly not the major factor explaining large-scale patterns of diversity in demersal fish assemblages, as suggested by Gaertner et al. (2007). However, it is difficult to compare our results with diversity values obtained with non-standardized data mainly collected from fish inventories from other works. Moreover, due to the limited sampling approach (i.e. data concerning only one guild of fishes or limited to specific depths, gear or habitat), some of regional inventories are useless for comparative studies (Psomadakis et al. 2012). Recent studies based mainly on standardized time series data also question the previously considered west-east decreasing diversity trend in the Mediterranean (Gaertner et al. 2013, Granger et al. 2015, Peristeraki et al. 2017).

The highest diversity values were found on the continental shelf of insular areas, such as the Balearic Islands, Sardinia, Sicily and the Aegean Sea. This higher diversity can be explained by taking into account the peculiarities of the distinct biogeographic sectors within the Mediterranean (Lejeusne et al. 2010), which can be characterized by the shallow water biota (Bianchi et al. 2012). In the Strait of Sicily, for example, the meeting of western and eastern Mediterranean species produces a peak in fish species richness in the central Mediterranean (Ben Rais Lasram et al. 2009, Garofalo et al. 2007). The greater sampling effort of the present work compared with previous ones (Morri et al. 1999, Koukouras et al. 2001) could affect the unexpectedly high diversity values found in the Aegean Sea. The presence of algae facies deeper than $50 \mathrm{~m}$ around the Balearic Islands is likely to enhance demersal fish diversity in this area. Coralligenous and maerl communities are very characteristic of the Mallorca-Menorca continental shelf up to 85-90 m depth (Canals and Ballesteros 1997, Ordines and Massutí 2009), and this has been pointed out as a plausible reason for the differences observed between the coastal demersal resources of the Balearic Islands and the adjacent Iberian Peninsula (Massutí and Reñones 2005). In fact, habitat type has been shown to affect the distribution of demersal species, most of them being more abundant and showing a better condition in maerl and Peyssonnelia beds (Ordines and Massutí 2009, Ordines et al. 2009, 2015), which have also shown high diversity of fish.

The results of SIMPER analyses reinforce the idea of maerl and Peyssonnelia beds causing high diversity values also on the continental shelves of Sicily, Sardinia and the Aegean Sea. The species Serranus cabrilla, Scyliorhinus canicula and Mullus surmuletus, which in the Balearic Islands have shown to be more abundant in these habitats (Ordines and Massutí 2009) contribute to $N_{90}$ mainly in this archipelago, Sardinia, Sicily and the Aegean Sea. Similar habitats to those found on the Balearic shelf have been reported in some of these areas, like the Aegean Sea (Georgiadis et al. 2009). The presence of a higher number of vulnerable species like demersal chondrichthyans in the Balearic Islands, Sardinia, Sicily and the Aegean Sea (Bertrand et al. 2000, Damalas and Vassilopoulou 2011, Ramírez-Amaro et al. 2015) compared with adjacent areas could also contribute to the higher fish diversity values found there.

The spatial distribution of the bottom trawl fishing effort by GSA shows that the number of vessels per $\mathrm{km}^{2}$ is low on the continental shelf of the Balearic Islands, Sardinia and the Aegean Sea (Colloca et al. 2017). The coincidence of areas with a low fishing effort with areas with a high diversity is in accordance with previous works, in which higher values of $N_{90}$ and $S$ and lower values of $J$ ' were associated with areas with a low fishing effort (Farriols et al. 2017). The lower fishing effort exerted by the relatively smaller bottom trawl fleets in these areas could have preserved, at least to some extent, their fish diversity along with a better conservation of their sensitive and essential habitats, such as maerl and Peyssonnelia beds. These habitats are precisely those most affected by the low selectivity and damaging collateral effects of bottom trawling on seabed communities, which decrease the presence of biogenic habitats, leading to a reduction in the biodiversity on exploited bottoms (e.g. Norse and Watling 1999, Smith et al. 2000, Hiddink et al. 2006).

Spatial patterns of demersal fish diversity on the shelf-break/upper slope and lower slope of the Mediterranean are different to those detected on the continental shelf. Areas with the highest diversity values on the continental shelf do not coincide with areas with the highest diversity values on the shelf break/ upper slope and lower slope. Although the assignment of depth strata was different in previous works and the comparison is not straightforward, a different pattern on shelf and slope areas was also observed for species richness (Gaertner et al. 2007, 2013). This is likely due to differences in the distribution of cumulative threats to marine biodiversity, which are mainly concentrated in coastal areas and on the continental shelf of the Mediterranean (Coll et al. 2012), and to the presence of particular habitats on the shelf break and slope bottoms, which may represent potential hot spots of biodiversity (Danovaro et al. 2010). Although the distribution of deep-sea diversity is different to that on the continental shelf, it is affected by similar factors: changes in spatial distribution of fishing effort together with habitat type. For example, higher $N_{90}$ values on the slope of northern Spain could be related to the presence of submarine canyons in the area where high values of biodiversity have been reported (see Fernández-Arcaya et al. 2017 for a review). However, the description of deep-sea habitats has just been implemented for some particular areas of the Mediterranean, and this information is not exhaustive at all (Danovaro et al. 2010). Moreover, an intensive habitat mapping based on MEDITS samples 
would be useful to relate demersal fish assemblages to their corresponding habitats, as has been done in some continental shelf areas (e.g. Ordines and Massutí 2009).

The outcomes of the present study show that at large temporal and spatial scales bottom trawl fisheries have reduced the diversity of demersal assemblages in the Mediterranean. However, in recent decades a generally stable scenario or even a slight recovery trend have been highlighted. This result would have not been expected if the alarming overexploitation status of Mediterranean stocks were taken into account, which underlines the importance of using diversity indices to study the effects of fishing on demersal assemblages. Therefore, a change from the assessment of demersal resources based on exploited monospecfic stocks to one based on the study of whole demersal fish assemblages is needed due to the high multispecificity of the bottom trawl fishery in the Mediterranean (Caddy 1993, Lleonart and Maynou 2003). The inclusion of species other than target ones made in this work through diversity indices is therefore important for the implementation of an ecosystem-based fisheries management (Browman and Stergiou 2004).

\section{ACKNOWLEDGEMENTS}

The present study could not have been done without the work of all participants and crew in the MEDITS scientific surveys, funded by the European Union Data Collection Framework for the Common Fisheries Policy, the funding projects supporting this research (ECLIPSAME Project CTM2012-37701 and CLIFISH project CTM2015-66400-C3-1-R MINECO/FEDER) and the FPI Fellowship (BES-2013-065112) from the Spanish Ministry of Economy and Competitiveness granted to MTF.

\section{REFERENCES}

Anticamara J.A., Watson R., Gelchu A., et al. 2011. Global fishing effort (1950-2010): Trends, gaps, and implications. Fish. Res. 107: $131-136$ https://doi.org/10.1016/j.fishres.2010.10.016

Ben Rais Lasram F., Guilhaumon F., Mouillot D. 2009. Fish diversity patterns in the Mediterranean Sea: deviations from a mid-domain model. Mar. Ecol. Prog. Ser. 376: 253-267. https://doi.org/10.3354/meps07786

Bertrand J.A., Gil de Sola L., Papakonstantinou C., et al. 2000. Contribution on the distribution of elasmobranchs in the Mediterranean (from the MEDITS surveys). Biol. Mar. Mediterr. 7: 385-399.

Bertrand J.A., Gil de Sola L., Papaconstantinou C., et al. 2002. The general specifications of the MEDITS surveys. Sci. Mar. 66: $9-17$. https://doi.org/10.3989/scimar.2002.66s29

Bianchi C.N., Morri C., Chiantore M., et al. 2012. Mediterranean Sea biodiversity between the legacy from the past and a future of change. In: Stambler N. (ed), Life in the Mediterranean Sea: a look at habitat changes. Nova Science Publishers, New York, pp. 1-55.

Bosc E., Bricaud A., Antoine D. 2004. Seasonal and interannual variability in algal biomass and primary production in the Mediterranean Sea, as derived from 4 years of SeaWiFS observations. Global Biogeochem. Cycles 18: GB1005. https://doi.org/10.1029/2003GB002034

Bray J.R., Curtis J.T. 1957. An ordination of the upland forest communities of southern Wisconsin. Ecol. Monogr. 27: 325-349. https://doi.org/10.2307/1942268

Browman H.I., Stergiou K.I. 2004. Perspectives on ecosystembased approaches to the management of marine resources. Mar. Ecol. Prog. Ser. 274: 269-303. https://doi.org/10.3354/meps274269

Caddy J.F. 1993. Some future perspectives for assessment and management of Mediterranean fisheries. Sci. Mar. 57: 121-130.

Callaway R., Alsvâg J., de Boois I., et al. 2002. Diversity and community structure of epibenthic invertebrates and fish in the North Sea. ICES J. Mar. Sci. 59: 1199-1214.

Canals M., Ballesteros E. 1997. Production of carbonate particles by phytobenthic communities on the Mallorca-Menorca shelf, northwestern Mediterranean Sea. Deep-Sea Res. Part II 44: 611-629. https://doi.org/10.1016/S0967-0645(96)00095-1

Cardinale M., Scarcella G. 2017. Mediterranean Sea: A Failure of the European Fisheries Management System. Front. Mar. Sci. 4: 72 . https://doi.org/10.3389/fmars.2017.00072

Ciannelli L., Fisher J.A.D., Skern-Mauritzen M., et al. 2013. Theory, consequences and evidence of eroding population spatial structure in harvested marine fishes: a review. Mar. Ecol. Prog. Ser. 480: 227-243. https://doi.org/10.3354/meps 10067

Clarke K.R. 1993. Non-parametric multivariate analyses of changes in community structure. Aust. J. Ecol. 18: 117-143. https://doi.org/10.1111/j.1442-9993.1993.tb00438.x

Clarke K.R., Gorley R.N., Somerfield P.J., et al. 2014. Change in marine communities: an approach to statistical analysis and interpretation. PRIMER-E, Plymouth, $260 \mathrm{pp}$.

Coll M., Piroddi C., Steenbeek J., et al. 2010. The biodiversity of the Mediterranean Sea: estimates, patterns, and threats. PloS ONE 5: e11842. https://doi.org/10.1371/journal.pone.0011842

Coll M., Piroddi C., Albouy C., et al. 2012. The Mediterranean Sea under siege: Spatial overlap between marine biodiversity, cumulative threats and marine reserves. Global Ecol. Biogeogr. 21: 465-480. https://doi.org/10.1111/j.1466-8238.2011.00697.x

Colloca F., Cardinale M., Belluscio A., et al. 2003. Pattern of distribution and diversity of demersal assemblages in the central Mediterranean Sea. Est. Coast. Shelf Sci. 56: 469-480. https://doi.org/10.1016/S0272-7714(02)00196-8

Colloca F., Cardinale M., Maynou F., et al. 2013. Rebuilding Mediterranean fisheries: toward a new paradigm for ecological sustainability in single species population models. Fish Fish. 14: 89-109. https://doi.org/10.1111/j.1467-2979.2011.00453.x

Colloca F., Scarcella G., Libralato S. 2017. Recent Trends and Impacts of Fisheries Exploitation on Mediterranean Stocks and Ecosystems. Front. Mar. Sci. 4: 244. https://doi.org/10.3389/fmars.2017.00244

Cury P., Bakun A., Crawford R.J.M., et al. 2000. Small pelagics in upwelling systems: patterns of interaction and structural changes in "wasp-waist" ecosystems. ICES J. Mar. Sci. 57: 603-618. https://doi.org/10.1006/jmsc.2000.0712

Daan N., Gislason H., Pope J.G., et al. 2005. Changes in the North Sea fish community: evidence of indirect effects of fishing? ICES J. Mar. Sci. 62: 177-188. https://doi.org/10.1016/j.icesjms.2004.08.020

Damalas D., Vassilopoulou V. 2011. Chondrichthyan by-catch and discards in the demersal trawl fishery of the central Aegean Sea (Eastern Mediterranean). Fish. Res. 108: 142-152. https://doi.org/10.1016/j.fishres.2010.12.012

Danovaro R., Dinet A., Duineveld G., et al. 1999. Benthic response to particulate fluxes in different trophic environments: a comparison between the Gulf of Lions-Catalan Sea (western-Mediterranean) and the Cretan Sea (eastern-Mediterranean). Progr. Oceanogr. 44: 287-312.

https://doi.org/10.1016/S0079-6611(99)00030-0

Danovaro R., Company J.B., Corinaldesi C., et al. 2010. Deep-sea biodiversity in the Mediterranean Sea: The known, the unknown, and the unknowable. PloS ONE 5: e11832. https://doi.org/10.1371/journal.pone.0011832

Dayton P.K., Thrush S.F., Agardy M.T., et al. 1995. Environmental effects of marine fishing. Aquat. Conserv. 5: 205-232. https://doi.org/10.1002/aqc.3270050305

Demestre M., Martín P. 1993. Optimum exploitation of a demersal resource in the western Mediterranean: the fishery of the deep- 
water shrimp Aristeus antennatus (Risso, 1816). Sci. Mar. 57: 175-182.

D’Onghia G., Mastrototaro F., Matarrese A., et al. 2003. Biodiversity of the upper slope demersal community in the eastern Mediterranean: preliminary comparison between two areas with and without trawl fishing. J. Northwest Atlantic Fish. Sci. 31: 263-273. https://doi.org/10.2960/J.v31.a20

Dremière P.Y., Fiorentini L., Cosimi G., et al. 1999. Escapement from the main body of the bottom trawl used for the Mediterranean international trawl survey (MEDITS). Aquat. Living Resour. 12: 207-217.

https://doi.org/10.1016/S0990-7440(00)88471-5

Duda A.M., Sherman K. 2002. A new imperative for improving management of large marine ecosystems. Ocean Coast. Manage. 45 : 797-833 https://doi.org/10.1016/S0964-5691(02)00107-2

Farriols M.T., Ordines F., Hidalgo M., et al. 2015. N90 index: a new approach to biodiversity based on similarity and sensitive to direct and indirect fishing impact. Ecol. Indic. 52: 245-255. https://doi.org/10.1016/j.ecolind.2014.12.009

Farriols M.T., Ordines F., Somerfield P.J., et al. 2017. Bottom trawl impacts on Mediterranean demersal fish diversity: Not so obvious or are we too late? Cont. Shelf Res. 137: 84-102. https://doi.org/10.1016/j.csr.2016.11.011

Farrugio H., Oliver P., Biagi F. 1993. An overview of the history, knowledge, recent and future research trends in Mediterranean fisheries. Sci. Mar. 57: 105-119.

Fernández-Arcaya U., Ramirez-Llodra E., Aguzzi J., et al. 2017. Ecological Role of Submarine Canyons and Need for Canyon Conservation: A Review. Front. Mar. Sci. 4: 5. https://doi.org/10.3389/fmars.2017.00005

Fiorentini L., Dremière P.Y., Leonori I., et al. 1999. Efficiency of the bottom trawl used for the Mediterranean international trawl survey (MEDITS): Efficacite du chalut de fond utilise pour le programme international d'evaluation des ressources halieutiques de Mediterranee (MEDITS). Aquat. Living. Resour. 12: $187-205$. https://doi.org/10.1016/S0990-7440(00)88470-3

Fortibuoni T., Libralato S., Raicevich S., et al. 2010. Coding Early Naturalists' Accounts into Long-Term Fish Community Changes in the Adriatic Sea (1800-2000). PLoS ONE 5: e15502. https://doi.org/10.1371/journal.pone.0015502

Fortibuoni T., Giovanardi O., Pranovi F., et al. 2017. Analysis of Long-Term Changes in a Mediterranean Marine Ecosystem Based on Fishery Landings. Front. Mar. Sci. 4: 33 https://doi.org/10.3389/fmars.2017.00204

Fromentin J.M., Fonteneau A. 2001. Fishing effects and life history traits: A case study comparing tropical versus temperate tunas. Fish. Res. 53: 133-150. https://doi.org/10.1016/S0165-7836(00)00299-X

Gaertner J.C., Bertrand J.A., Relini G., et al. 2007. Spatial pattern in species richness of demersal fish assemblages on the continental shelf of the northern Mediterranean Sea: A multiscale analysis. Mar. Ecol. Prog. Ser. 341: 191-203. https://doi.org/10.3354/meps341191

Gaertner J.C., Maiorano P., Mérigot B., et al. 2013. Large-scale diversity of slope fishes: pattern inconsistency between multiple diversity indices. PloS ONE 8: e66753. https://doi.org/10.1371/journal.pone.0066753

García-Ruiz C., Lloris D., Rueda J.L., et al. 2015. Spatial distribution of ichthyofauna in the northern Alboran Sea (western Mediterranean). J. Nat. Hist. 49: 1191-1224. https://doi.org/10.1080/00222933.2014.1001457

Garofalo G., Fiorentino F., Gristina M., et al. 2007. Stability of spatial pattern of fish species diversity in the Strait of Sicily (central Mediterranean). Hydrobiologia 580: 117-124. https://doi.org/10.1007/s10750-006-0460-1

Georgiadis M., Papatheodoroy G., Tzanatos E., et al. 2009. Coralligene formations in the eastern Mediterranean SeaQ Morphology, distribution mapping and relations to fisheries in the South Aegean Sea (Greece) based on high-resolution acoustics. J. Exper. Biol. Ecol. 368: 44-58. https://doi.org/10.1016/j.jembe.2008.10.001

General Fisheries Commission for the Mediterranean (GFCM). 2016. Report of the Working Group on Stock Assessment of Demersal Species (WGSAD). Rome.

http://www.fao.org/gfcm/reports/technical-meetings/detail/ $\mathrm{en} / \mathrm{c} / 471253 /$

Gislason H. 2002. The effects of fishing on non-target species and ecosystem structure and function. In: Sinclair M., Valdimarsson G. (eds), Responsible Fisheries in the Marine Ecosystem. CAB International, Wallingford, pp. 255-274. https://doi.org/10.1079/9780851996332.0255

Granger V., Fromentin J.-M., Bez N., et al. 2015. Large-scale spatio-temporal monitoring highlights hotspots of demersal fish diversity in the Mediterranean Sea. Prog. Oceanogr. 130: 65-74. https://doi.org/10.1016/j.pocean.2015.08.002

Guijarro B., Massutí E., Moranta J., et al. 2008. Population dynamics of the red shrimp Aristeus antennatus in the Balearic Islands (western Mediterranean): Short spatio-temporal differences and influence of environmental factors. J. Mar. Syst. 71: 385-402. https://doi.org/10.1016/j.jmarsys.2007.04.003

Hall S.J. 1999. The Effects of Fishing on Marine Ecosystems and Communities. Blackwell Science, Oxford. 274 pp.

Hiddink J.G., Jennings S., Kaiser M.J., et al. 2006. Cumulative impacts of seabed trawl disturbance on benthic biomass, production, and species richness in different habitats. Can. J. Fish. Aquat. Sci. 63: 721-736. https://doi.org/10.1139/f05-266

Jennings S., Dulvy N.K. 2005. Reference points and reference directions for size-based indicators of community structure. ICES J. Mar. Sci. 62: 397-404. https://doi.org/10.1016/j.icesjms.2004.07.030

Jørgensen C., Enberg K., Dunlop E.S., et al. 2007. Managing Evolving Fish Stocks. Science 318: 1247-1248. https://doi.org/10.1126/science.1148089

Kaiser M.J., de Groot S.J. 2000. The effects of fishing on non-target species and habitats. Biological, conservation and socio-economics issues. Blackwell Science, Oxford, $399 \mathrm{pp}$.

Kaiser M.J., Collie J.S., Hall S.J., et al. 2002. Modification of marine habitats by trawling activities: prognosis and solutions. Fish Fish. 3: 114-136. https://doi.org/10.1046/j.1467-2979.2002.00079.x

Koukouras A., Voultsiadou E., Kitsos M.S., et al. 2001. Macrobenthic fauna diversity in the Aegean Sea, affinities with other Mediterranean regions and the Black Sea. Bios 6: 61-76.

Labropoulou M., Papaconstantinou C. 2004. Community structure and diversity of demersal fish communities: the role of fishery. Sci. Mar. 68: 215-226. https://doi.org/10.3989/scimar.2004.68s1215

Lejeusne C., Chevaldonné P., Pergent-Martini C., et al. 2010. Climate change effects on a miniature ocean: the highly diverse, highly impacted Mediterranean Sea. Trends Ecol. Evol. 25: $250-260$. https://doi.org/10.1016/j.tree.2009.10.009

Lleonart J., Maynou F. 2003. Fish stock assessments in the Mediterranean: state of the art. Sci. Mar. 67: 37-49. https://doi.org/10.3989/scimar.2003.67s137

Masnadi F., Criscoli A., Lanteri L., et al. 2018. Effects of environmental and anthropogenic drivers on the spatial distribution of deep-sea shrimps in the Ligurian and Tyrrhenian Seas (NW Mediterranean). Hydrobiologia 816: 165-178. https://doi.org/10.1007/s10750-018-3581-4

Massutí E., Reñones O. 2005. Demersal resource assemblages in the trawl fishing grounds off the Balearic Islands (western Mediterranean). Sci. Mar. 69: 167-181. https://doi.org/10.3989/scimar.2005.69n1167

MEDITS Working Group. 2017. MEDITS-Handbook, Version n. 9. MEDITS Working Group, $106 \mathrm{pp}$. http://www.sibm.it/MEDITS\%202011/principaledownload.htm

Meléndez M.J., Báez J.C., Serna-Quintero J.M., et al. 2017. Historical and ecological drivers of the spatial pattern of Chondrichthyes species richness in the Mediterranean Sea. PLoS ONE 12: e1075699. https://doi.org/10.1371/journal.pone.0175699

Moranta J., Quetglas A., Massutí E., et al. 2008. Research trends on demersal fisheries oceanography in the Mediterranean. In: Mertens L.P. (ed), Biological Oceanograpgy Research Trends. Nova Science Publishers, New York, pp. 9-65.

Morato T., Watson R., Pitcher T.J., et al. 2006. Fishing down the deep. Fish Fish. 7: 24-34 https://doi.org/10.1111/j.1467-2979.2006.00205.x

Morri C., Bianchi C.N., Cocito S., et al. 1999. Biodiversity of marine sessile epifauna at an Aegean island subject to hydrothermal activity: Milos, Eastern Mediterranean Sea. Mar. Biol. 135: 729-739. https://doi.org/10.1007/s002270050674

Murawski S.A. 2000. Definitions of overfishing from an ecosystem perspective. ICES J. Mar. Sci. 57: 649-658. 
https://doi.org/10.1006/jmsc.2000.0738

Norse E.A., Watling L. 1999. Impacts of mobile fishing gear: the biodiversity perspective. Am. Fish. Soc. Symp. 22: 31-40.

Ordines F., Massutí E. 2009. Relationships between macro-epibenthic communities and fish on the shelf grounds of the western Mediterranean. Aquat. Conserv.: Mar. Freshw. Ecosyst. 19: 370-383. https://doi.org/10.1002/aqc.969

Ordines F., Quetglas A., Massutí E., et al. 2009. Habitat preferences and life history of the red scorpion fish, Scorpaena notata, in the Mediterranean. Est. Coast. Shelf Sci. 85: 537-546. https://doi.org/10.1016/j.ecss.2009.09.020

Ordines F., Farriols M.T., Lleonart J., et al. 2014. Biology and population dynamics of by-catch fish species of the bottom trawl fishery in the western Mediterranean. Mediterr. Mar. Sci. 15: $613-625$. https://doi.org/10.12681/mms.812

Ordines F., Bauzá M., Sbert M., et al. 2015. Red algal beds increase the condition of nekto-benthic fish. J. Sea Res. 95: 115-123. https://doi.org/10.1016/j.seares.2014.08.002

Peristeraki P., Tserpes G., Lampadariou N., et al. 2017. Comparing demersal megafaunal species diversity along the depth gradient within the South Aegean and Cretan Seas (Eastern Mediterranean). PLoS ONE 12: e0184241. https://doi.org/10.1371/journal.pone.0184241

Pranovi F., Raicevich S., Franceschini G., et al. 2001. Discard analysis and damage to non-target species in the 'rapido' trawl fishery. Mar. Biol. 139: 863-875 https://doi.org/10.1007/s002270100646

Psomadakis P.N., Giustino S., Vacchi M. 2012. Mediterranean fish biodiversity: An updated inventory with focus on the Ligurian and Tyrrhenian seas. Zootaxa 3263: 1-46. https://doi.org/10.11646/zootaxa.3263.1.1

Quetglas A., Merino G., González J., et al. 2017. Harvest Strategies for an Ecosystem Approach to Fisheries Management in Western Mediterranean Demersal Fisheries. Front. Mar. Sci. 4: 106. https://doi.org/10.3389/fmars.2017.00106

Quignard J.P., Tomasini J.A. 2000. Mediterranean fish diversity. Biol. Mar. Mediterr. 7: 1-66.

R Core Team. 2014. R: A Language and Environment for Statistical Computing. http://www.r-project.org/.

Ramírez-Amaro S., Ordines F., Terrasa B., et al. 2015. Demersal chondrichthyans in the western Mediterranean: Assemblages and biological parameters of their main species. Mar. Freshw. Res. 67: 636-652. https://doi.org/10.1071/MF15093

Rice J.C. 2000. Evaluating fishery impacts using metrics of community structure. ICES J. Mar. Sci. 57: 682-688. https://doi.org/10.1006/jmsc.2000.0735

Roberts C.M. 2002. Deep impact: the rising toll of fishing in the deep sea. Trends Ecol. Evol. 17: 242-245. https://doi.org/10.1016/S0169-5347(02)02492-8

Sabatini A., Locci I., Deiana A.M., et al. 2013. Temporal trends in biodiversity of the middle-slope assemblages in Sardinian seas (Central-Western Mediterranean). J. Mar. Biol. Ass. U.K. 93: 1739-1752. https://doi.org/10.1017/S0025315413000258

Sardà F., Calafat A., Flexas M.M., et al. 2004. An introduction to Mediterranean deep-sea biology. Sci. Mar. 68: 7-38. https://doi.org/10.3989/scimar.2004.68s37

Sartor P., Colloca F., Maravelias C., et al. 2014. Critical assessment of the current understanding/knowledge of the framework of the Ecosystem Approach to Fisheries in the Mediterranean and Black Seas. Sci. Mar. 78: 19-27.

https://doi.org/10.3989/scimar.04021.17B

Smith C., Papadopoulou K.N., Diliberto S. 2000. Impact of otter trawling on an eastern Mediterranean commercial trawl fishing ground. ICES J. Mar. Sci. 57: 1340-1351. https://doi.org/10.1006/jmsc.2000.0927

Tecchio S., Ramírez-Llodra E., Sardà F., et al. 2011. Drivers of deep Mediterranean megabenthos communities along longitudinal and bathymetric gradients. Mar. Ecol. Prog. Ser. 439: 181-192. https://doi.org/10.3354/meps09333

Tserpes G., Peristeraki P., Potamias G., et al. 1999. Species distribution in the southern Aegean sea based on bottom-trawl surveys, Aquat. Living Resour. 12: 167-175. https://doi.org/10.1016/S0990-7440(00)88468-5

Tserpes G., Tzanatos E., Peristeraki P. 2011. Spatial management of the Mediterranean bottom-trawl fisheries: the case of the southern Aegean Sea. Hydrobiologia 670: 267-274. https://doi.org/10.1007/s10750-011-0667-7

Ungaro N., Marano G., Marsan R., et al. 1998. Demersal fish assemblage biodiversity as an index of fishery resources exploitation. Ital. J. Zool. 65: 511-516. https://doi.org/10.1080/11250009809386876

Ungaro N., Marano G., Marsan R., et al. 1999. Analysis of demersal assemblages from trawl surveys in the South Adriatic Sea. Aquat. Living. Resour. 12: 177-185. https://doi.org/10.1016/S0990-7440(00)88469-7

Zhou S., Smith A.D.M., Punt A.E., et al. 2010. Ecosystem-based fisheries management requires a change to the selective fishing philosophy. PNAS 107: 9485-9489. https://doi.org/10.1073/0pnas.0912771107

\section{SUPPLEMENTARY MATERIAL}

The following supplementary material is available through the online version of this article and at the following link: http://scimar.icm.csic.es/scimar/supplm/sm04977esm.pdf

Table S1. - Temporal series of fishing effort measures in number of vessels, kilowatt per day at sea $\left(\mathrm{kW}^{*}\right.$ days at sea) and gross tonnage per days at sea (GT*days at sea) for each GSA and species. Species considered in each depth stratum are i) Mullus barbatus or Mullus surmuletus for the continental shelf; ii) Nephrops norvegicus or Parapenaeus longirostris for the shelf break/ upper slope; and iii) Aristeus antennatus or Aristaeomorpha foliacea for the lower slope. Effort measures used to calculate trends in fishing effort for each GSA and stratum are marked with (*). References are listed below the table.

Fig. S1. - Species accumulation curves for each GSA. Note that for all GSAs asymptotic values of species counts are reached.

Fig. S2. - Mean values of $N_{90}$ diversity index during the period 1994-2015 for each GSA and depth strata. Black dots, shelf; blue dots, shelf break/upper slope; red dots, lower slope.

Fig. S3. - Mean values of species richness $(S)$ during the period 1994-2015 for each GSA and depth strata. Black dots, shelf; blue dots, shelf break/upper slope; red dots, lower slope.

Fig. S4. - Mean values of Pielou evennes $\left(J^{\prime}\right)$ during the period 1994-2015 for each GSA and depth strata. Black dots, shelf; blue dots, shelf break/upper slope; red dots, lower slope. 


\section{Spatio-temporal trends in diversity of demersal fish assemblages in the Mediterranean}

M. Teresa Farriols, Francesc Ordines, Pierluigi Carbonara, Loredana Casciaro, Manfredi Di Lorenzo, Antonio Esteban, Cristina Follesa, Cristina García-Ruiz, Igor Isajlovic, Angélique Jadaud, Alessandro Ligas, Chiara Manfredi, Bojan Marceta, Panagiota Peristeraki, Nedo Vrgoc, Enric Massutí

Supplementary material 
Table S1. - Temporal series of fishing effort measures in number of vessels, kilowatt per days at sea (kW*days at sea) and gross tonnage per days at sea (GT*days at sea) for each GSA and species. Species considered in each depth stratum are i) Mullus barbatus or Mullus surmuletus for the continental shelf; ii) Nephrops norvegicus or Parapenaeus longirostris for the shelf break/upper slope; and iii) Aristeus antennatus or Aristaeomorpha foliacea for the lower slope. Effort measures used to calculate trends in fishing effort for each GSA and stratum are marked with (*). References are listed below the table.

\begin{tabular}{|c|c|c|c|c|}
\hline GSA & Species & Effort measure & Years & Reference \\
\hline \multirow[t]{3}{*}{ GSA 1} & M. barbatus & Number of vessels & $2005-2007$ & SAC GFCM 2008a \\
\hline & M. barbatus & $\mathrm{kW}^{*}$ days at sea $(*), \mathrm{GT}^{*}$ days at sea & 2009-2013 & STECF 2015a \\
\hline & P. longirostris & $\mathrm{kW}^{*}$ days at sea $(*)$ & 2003-2015 & STECF 2016b \\
\hline \multirow[t]{10}{*}{ GSA 5} & A. antennatus & Number of vessels $(*)$ & 2011 & SAC GFCM 2012a \\
\hline & A. antennatus & Number of vessels (*) & 1998-2009 & SAC GFCM 2010a \\
\hline & A. antennatus & Number of vessels (*) & 1999-2010 & SAC GFCM 2011a \\
\hline & M. barbatus & Number of vessels & 2000-2009 & SAC GFCM 2010b \\
\hline & M. barbatus & $\mathrm{kW}^{*}$ days at sea, $\mathrm{GT}^{*}$ days at sea & 2009-2012 & STECF 2013b \\
\hline & M. surmuletus & Number of vessels & 2000-2009 & SAC GFCM 2010c \\
\hline & M. surmuletus & Number of vessels $(*)$ & $2000-2010$ & SAC GFCM 2011b \\
\hline & $N$. norvegicus & Number of vessels (*) & 2002-2009 & SAC GFCM 2010d \\
\hline & N. norvegicus & $\mathrm{kW} *$ days at sea, GT*days at sea & 2009-2013 & STECF $2015 \mathrm{a}$ \\
\hline & P. longirostris & $\mathrm{kW}^{*}$ days at sea, GT*days at sea & 2009-2012 & STECF 2013a \\
\hline \multirow[t]{10}{*}{ GSA 6} & A. antennatus & Number of vessels & 1996-2006 & SAC GFCM 2007 \\
\hline & A. antennatus & $\mathrm{kW}^{*}$ days at sea, $\mathrm{GT}^{*}$ days at sea & $2009-2014$ & STECF 2015b \\
\hline & M. barbatus & Number of vessels $(*)$ & 1999-2010 & SAC GFCM 2011c \\
\hline & M. barbatus & Number of vessels, $\mathrm{kW}^{*}$ days at sea, GT*days at sea & 2009-2012 & STECF 2013b \\
\hline & M. surmuletus & Number of vessels $(*)$ & $1998-2009$ & SAC GFCM 2010e \\
\hline & N. norvegicus & Number of vessels (*), $\mathrm{kW}^{*}$ days at sea, GT*days at sea & 2004-2015 & STECF 2016b \\
\hline & P. longirostris & Number of vessels & $2001-2010$ & SAC GFCM 2011d \\
\hline & P. longirostris & Number of vessels & 2001-2011 & SAC GFCM 2012b \\
\hline & P. longirostris & Number of vessels & 2001-2012 & SAC GFCM 2013 \\
\hline & P. longirostris & Number of vessels, $\mathrm{kW}^{*}$ days at sea, GT*days at sea & 2009-2012 & STECF 2013a \\
\hline \multirow[t]{6}{*}{ GSA 7} & M. barbatus & Number of vessels & $2002-2013$ & STECF 2014a \\
\hline & M. barbatus & Days at sea, $\mathrm{kW}^{*}$ days at sea, $\mathrm{GT}^{*}$ days at sea & 2004-2006 & STECF 2008a \\
\hline & M. barbatus & Number of vessels & 2004-2008 & SAC GFCM 2009a \\
\hline & M. barbatus & Number of vessels & 2004-2009 & SAC GFCM $2010 f$ \\
\hline & M. barbatus & Number of vessels $(*)$ & 2004-2011 & SAC GFCM 2012c \\
\hline & M. surmuletus & Number of vessels & 2004-2010 & SAC GFCM 2011e \\
\hline \multirow{7}{*}{ GSA 9} & A. foliacea & $\mathrm{kW}^{*}$ days at sea & 2004-2012 & STECF 2013a \\
\hline & A. foliacea & $\mathrm{kW}^{*}$ days at sea $(*)$ & 2004-2014 & STECF $2015 b$ \\
\hline & $N$. norvegicus & $\mathrm{kW}^{*}$ days at sea & 2004-2013 & STECF 2014a \\
\hline & N. norvegicus & Number of vessels, $\mathrm{kW}^{*}$ days at sea, GT*days at sea & 2004-2015 & STECF 2016b \\
\hline & P. longirostris & $\mathrm{kW}^{*}$ days at sea $(*)$ & $2002-2015$ & STECF 2016b \\
\hline & P. longirostris & $\mathrm{kW}^{*}$ days at sea & 2004-2013 & STECF 2015a \\
\hline & P. longirostris & Number of vessels & 2006-2008 & SAC GFCM 2009b \\
\hline \multirow[t]{3}{*}{ GSA 10} & A. foliacea & $\mathrm{kW}^{*}$ days at sea & 2004-2014 & STECF 2015b \\
\hline & P. longirostris & $\mathrm{kW}^{*}$ days at sea $(*)$ & $2002-2015$ & STECF $2016 b$ \\
\hline & P. longirostris & $\mathrm{kW}^{*}$ days at sea & 2004-2012 & STECF 2013a \\
\hline \multirow[t]{4}{*}{ GSA 11} & A. foliacea & Number of vessels, $\mathrm{kW}^{*}$ days at sea $(*), \mathrm{GT}^{*}$ days at sea & 2004-2014 & STECF $2015 b$ \\
\hline & M. surmuletus & $\mathrm{GT}^{*}$ days at sea $(*)$ & 2004-2012 & STECF 2013b \\
\hline & N. norvegicus & Number of vessels, $\mathrm{kW}^{*}$ days at sea, GT*days at sea & 2004-2015 & STECF 2016b \\
\hline & P. longirostris & $\mathrm{kW}^{*}$ days at sea $(*)$ & 2002-2015 & STECF 2016b \\
\hline GSA 15-16 & A. foliacea & $\mathrm{GT}^{*}$ days at sea & 2004-2008 & SAC GFCM 2009c \\
\hline GSA 16 & P. longirostris & Number of vessels & 2006-2007 & SAC GFCM 2008b \\
\hline \multirow[t]{2}{*}{ GSA 17} & M. barbatus & $\mathrm{kW}^{*}$ days at sea $(*), \mathrm{GT}^{*}$ days at sea & 2004-2012 & STECF 2013b \\
\hline & $N$. norvegicus & $\mathrm{kW}^{*}$ days at sea $(*)$ & $2002-2015$ & STECF 2016b \\
\hline \multirow{2}{*}{ GSA $17-18$} & M. barbatus & $\mathrm{kW}^{*}$ days at sea, $\mathrm{GT}^{*}$ days at sea & 2004-2014 & STECF 2016a \\
\hline & N. norvegicus & $\mathrm{kW}^{*}$ days at sea, GT*days at sea & 2006-2014 & STECF $2016 \mathrm{a}$ \\
\hline \multirow[t]{3}{*}{ GSA 18} & A. foliacea & $\mathrm{kW}^{*}$ days at sea $(*), \mathrm{GT}^{*}$ days at sea & 2002-2014 & STECF 2016a \\
\hline & M. barbatus & $\mathrm{kW} *$ days at sea $(*)$ & 2004-2013 & STECF 2015a \\
\hline & P. longirostris & $\mathrm{kW}^{*}$ days at sea, GT*days at sea $(*)$ & 2007-2014 & STECF $2016 a$ \\
\hline GSA $22-23$ & P. longirostris & Days at sea, $\mathrm{kW}^{*}$ days at sea, $\mathrm{GT}^{*}$ days at sea & 2003-2006 & STECF 2008a \\
\hline
\end{tabular}

SAC GFCM. 2007. Scientific Advisory Committee on Fisheries of the General Fisheries Comission of the Mediterranean (SAC GFCM) Stock assessment forms of the Sub-Committee on Stock Assessment - Aristeus antennatus - GSA 6. FAO.

SAC GFCM. 2008a. Scientific Advisory Committee on Fisheries of the General Fisheries Comission of the Mediterranean (SAC GFCM) Stock assessment forms of the Sub-Committee on Stock Assessment - Mullus barbatus - GSA 1. FAO.

SAC GFCM. 2008b. Scientific Advisory Committee on Fisheries of the General Fisheries Comission of the Mediterranean (SAC GFCM) Stock assessment forms of the Sub-Committee on Stock Assessment - Parapenaeus longirostris - GSA 16. FAO.

SAC GFCM. 2009a. Scientific Advisory Committee on Fisheries of the General Fisheries Comission of the Mediterranean (SAC GFCM) Stock assessment forms of the Sub-Committee on Stock Assessment - Mullus barbatus - GSA 7. FAO.

SAC GFCM. 2009b. Scientific Advisory Committee on Fisheries of the General Fisheries Comission of the Mediterranean (SAC GFCM) Stock assessment forms of the Sub-Committee on Stock Assessment - Parapenaeus longirostris - GSA 9. FAO.

SAC GFCM. 2009c. Scientific Advisory Committee on Fisheries of the General Fisheries Comission of the Mediterranean (SAC GFCM) Stock assessment forms of the Sub-Committee on Stock Assessment - Aristeus antennatus - GSAs 15 \& 16 . FAO.

SAC GFCM. 2010a. Scientific Advisory Committee on Fisheries of the General Fisheries Comission of the Mediterranean (SAC GFCM) Stock assessment forms of the Sub-Committee on Stock Assessment - Aristeus antennatus - GSA 5. FAO.

SAC GFCM. 2010b. Scientific Advisory Committee on Fisheries of the General Fisheries Comission of the Mediterranean (SAC GFCM) Stock assessment forms of the Sub-Committee on Stock Assessment - Mullus barbatus - GSA 5. FAO.

SAC GFCM. 2010c. Scientific Advisory Committee on Fisheries of the General Fisheries Comission of the Mediterranean (SAC GFCM) Stock assessment forms of the Sub-Committee on Stock Assessment - Mullus surmuletus - GSA 5. FAO.

SAC GFCM. 2010d. Scientific Advisory Committee on Fisheries of the General Fisheries Comission of the Mediterranean (SAC GFCM) - 
Stock assessment forms of the Sub-Committee on Stock Assessment - Nephrops norvegicus - GSA 5. FAO.

SAC GFCM. 2010e. Scientific Advisory Committee on Fisheries of the General Fisheries Comission of the Mediterranean (SAC GFCM) Stock assessment forms of the Sub-Committee on Stock Assessment - Mullus barbatus - GSA 6. FAO.

SAC GFCM. 2010f. Scientific Advisory Committee on Fisheries of the General Fisheries Comission of the Mediterranean (SAC GFCM) Stock assessment forms of the Sub-Committee on Stock Assessment - Mullus barbatus - GSA 7. FAO.

SAC GFCM. 2011a. Scientific Advisory Committee on Fisheries of the General Fisheries Comission of the Mediterranean (SAC GFCM) Stock assessment forms of the Sub-Committee on Stock Assessment - Aristeus antennatus - GSA 5. FAO.

SAC GFCM. 2011b. Scientific Advisory Committee on Fisheries of the General Fisheries Comission of the Mediterranean (SAC GFCM) Stock assessment forms of the Sub-Committee on Stock Assessment - Mullus surmuletus - GSA 5. FAO.

SAC GFCM. 2011c. Scientific Advisory Committee on Fisheries of the General Fisheries Comission of the Mediterranean (SAC GFCM) Stock assessment forms of the Sub-Committee on Stock Assessment - Mullus barbatus - GSA 6. FAO.

SAC GFCM. 2011d. Scientific Advisory Committee on Fisheries of the General Fisheries Comission of the Mediterranean (SAC GFCM) Stock assessment forms of the Sub-Committee on Stock Assessment - Parapenaeus longirostris - GSA 6. FAO.

SAC GFCM. 2011e. Scientific Advisory Committee on Fisheries of the General Fisheries Comission of the Mediterranean (SAC GFCM) Stock assessment forms of the Sub-Committee on Stock Assessment - Mullus barbatus - GSA 7. FAO.

SAC GFCM. 2012a. Scientific Advisory Committee on Fisheries of the General Fisheries Comission of the Mediterranean (SAC GFCM) Stock assessment forms of the Sub-Committee on Stock Assessment - Aristeus antennatus - GSA 5. FAO.

SAC GFCM. 2012b. Scientific Advisory Committee on Fisheries of the General Fisheries Comission of the Mediterranean (SAC GFCM) Stock assessment forms of the Sub-Committee on Stock Assessment - Parapenaeus longirostris - GSA 6. FAO

SAC GFCM. 2012c. Scientific Advisory Committee on Fisheries of the General Fisheries Comission of the Mediterranean (SAC GFCM) Stock assessment forms of the Sub-Committee on Stock Assessment - Mullus barbatus - GSA 7. FAO.

SAC GFCM. 2013. Scientific Advisory Committee on Fisheries of the General Fisheries Comission of the Mediterranean (SAC GFCM) Stock assessment forms of the Sub-Committee on Stock Assessment - Parapenaeus longirostris - GSA 6. FAO.

STECF. 2008a. Scientific, Technical and Economic Committee for Fisheries (STECF) - Report of the SGMED-08-03 Working Group on the Mediterranean Part III Joint Black SeaWorking Group, STECF.

STECF. 2013a. Scientific, Technical and Economic Committee for Fisheries (STECF) - 2013 Assessment of Mediterranean Sea stocks part I (STECF 13-22). Publications Office of the European Union: Luxembourg.

STECF. 2013b. Scientific, Technical and Economic Committee for Fisheries (STECF) - 2013 Assessment ofMediterranean Sea stocks part II (STECF-14-08). Publications Office of the European Union: Luxembourg.

STECF. 2014a. Scientific, Technical and Economic Committee for Fisheries (STECF) - Assessment of Mediterranean Sea Stocks - Part 1 (STECF-14-17). Publications Office of the European Union: Luxembourg.

STECF. 2015a. Scientific, Technical and Economic Committee for Fisheries (STECF) - Mediterranean Assessments Part 2 (STECF-15-06). Publications Office of the European Union: Luxembourg.

STECF. 2015b. Scientific, Technical and Economic Committee for Fisheries (STECF) - Mediterranean Assessments Part 1 (STECF-15-18). Publications Office of the European Union: Luxembourg.

STECF. 2016a. Reports of the Scientific, Technical and Economic Committee for Fisheries (STECF) - Mediterranean assessments part 2 (STECF-16-08). Publications Office of the European Union: Luxembourg.

STECF. 2016b. Reports of the Scientific, Technical and Economic Committee for Fisheries (STECF) - Mediterranean assessments part 2 (STECF-17-06). Publications Office of the European Union: Luxembourg.
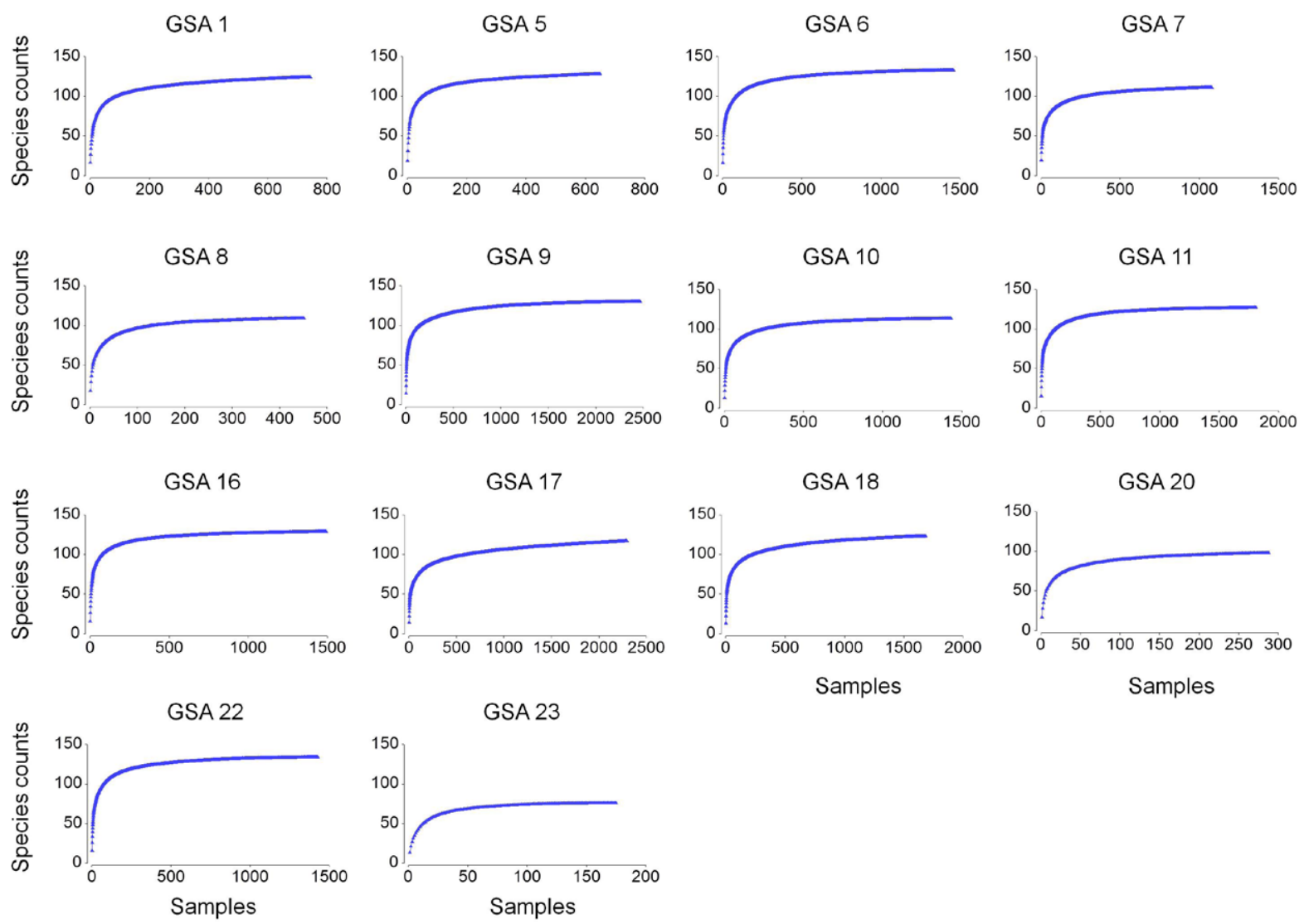

GSA 23

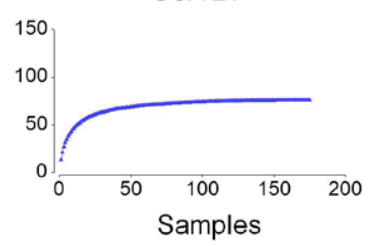

Fig. S1. - Species accumulation curves for each GSA. Note that for all GSAs asymptotic values of species counts are reached. 

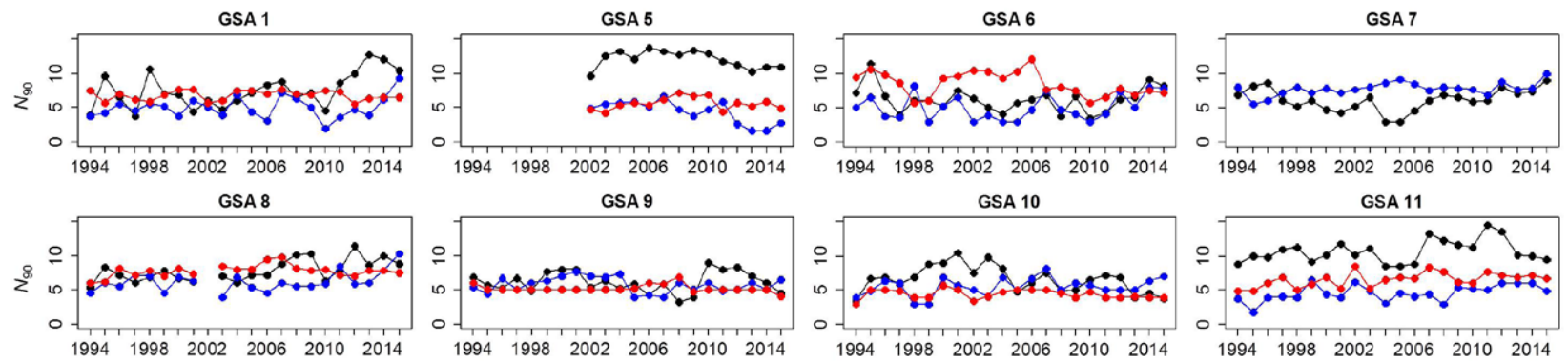

GSA 11

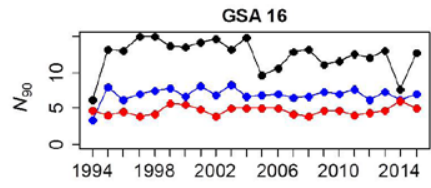

GSA 17

GSA 18
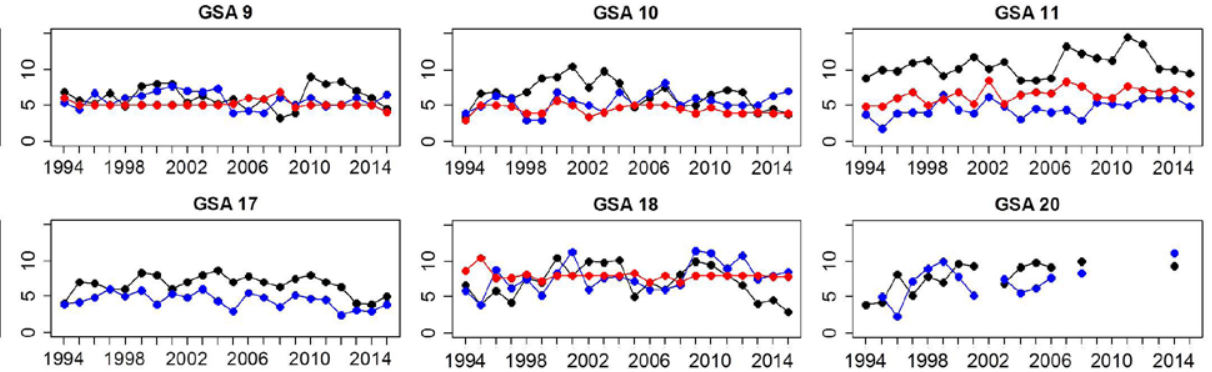

GSA 20

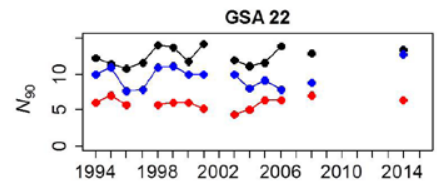

Year

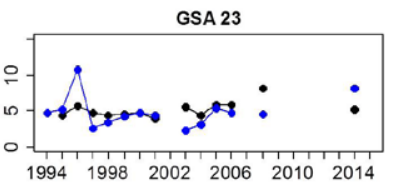

Year

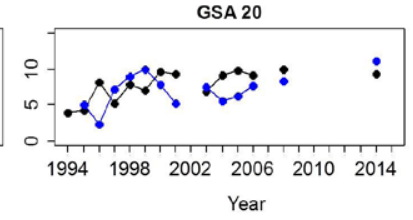

Fig. S2. - Mean values of $N_{90}$ diversity index during the period 1994-2015 for each GSA and depth strata. Black dots, shelf; blue dots, shelf break/upper slope; red dots, lower slope.

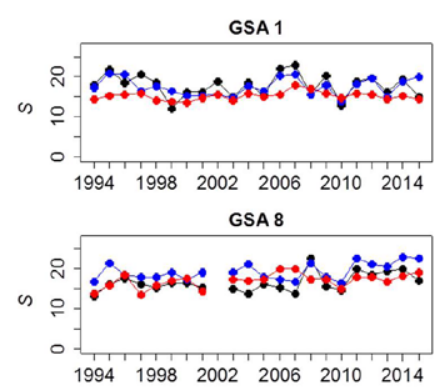

GSA 16

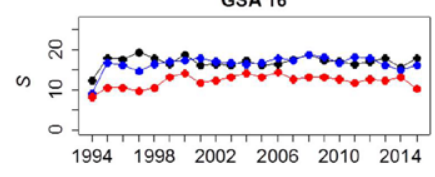

GSA 22

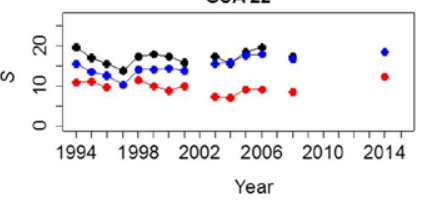

GSA 5

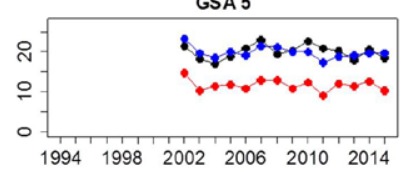

GSA 9

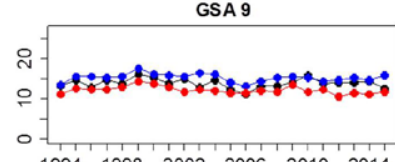

GSA 17

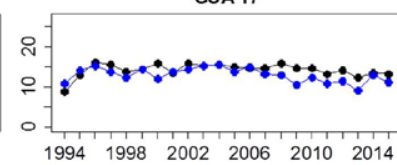

GSA 23
GSA 6

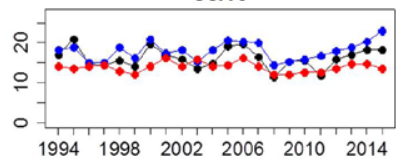

GSA 10

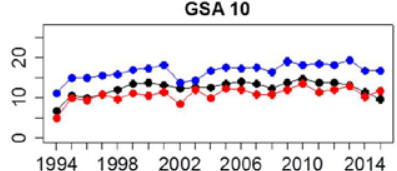

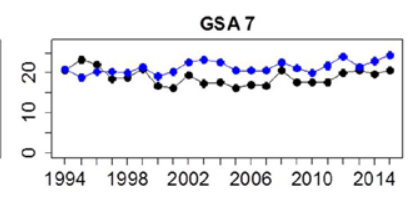

GSA 11

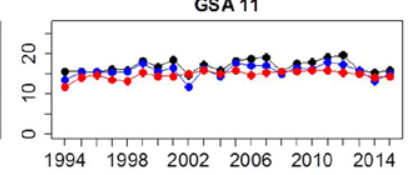

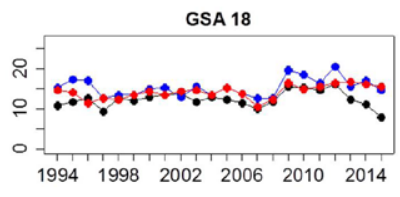

GSA 20

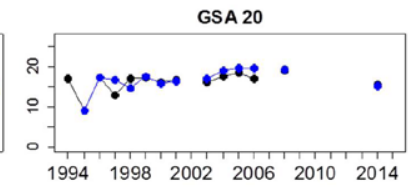

Year

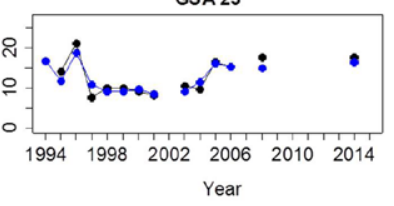

Fig. S3. - Mean values of species richness $(S)$ during the period 1994-2015 for each GSA and depth strata. Black dots, shelf; blue dots, shelf break/upper slope; red dots, lower slope. 
GSA 1

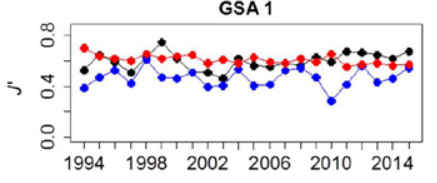

GSA 8

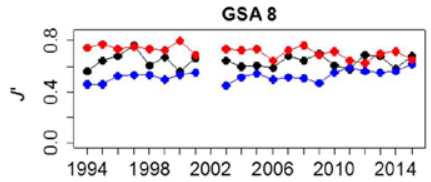

GSA 16

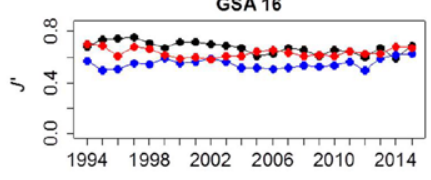

GSA 22

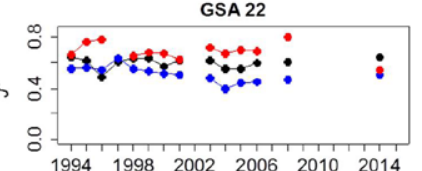

Year

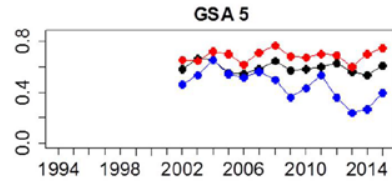

GSA 9

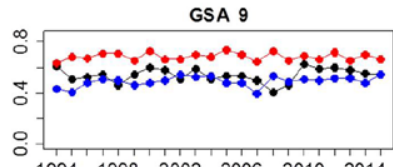

GSA 17

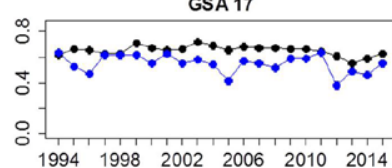

GSA 23

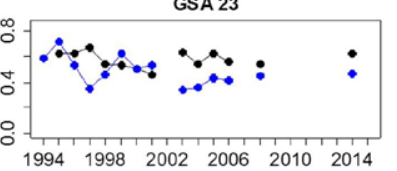

Year
GSA 6

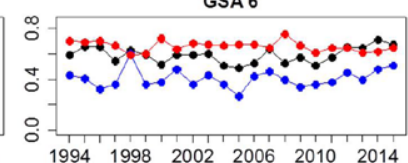

GSA 10

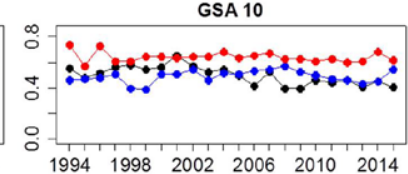

GSA 18

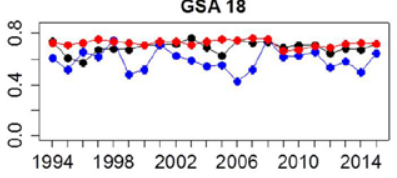

Year
GSA 7

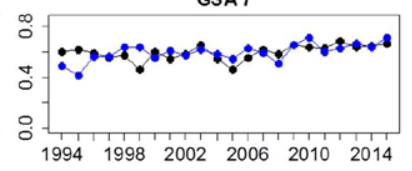

GSA 11

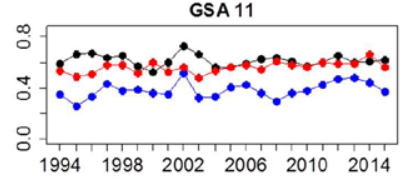

GSA 20

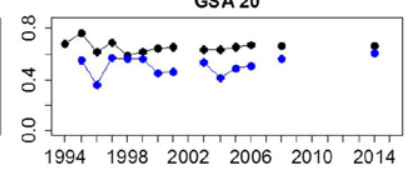

Year

Fig. S4. - Mean values of Pielou evennes ( $\left.J^{\prime}\right)$ during the period 1994-2015 for each GSA and depth strata. Black dots, shelf; blue dots, shelf break/upper slope; red dots, lower slope 